CHARLOTTE CONNELL

\title{
THE RIGHT TO LANGUAGE AND ITS CONTEMPORARY SIGNIFICANCE FOR NEW ZEALAND
}

\section{LLM RESEARCH PAPER}

PUBLIC LAW - EXPLORING THE EDGE (LAWS 505)

LAW FACULTY

VICTORIA UNIVERSITY OF WELLINGTON 


\section{Victoria \\ UNIVERSITY OF WELLINGTON \\ Te Whare Wananga \\ o re Ũpoko o te Ika a Mäui

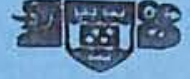

\section{IIIBRARY}




\section{CONTENTS}

CONTENTS... $i$

ABSTRACT iii

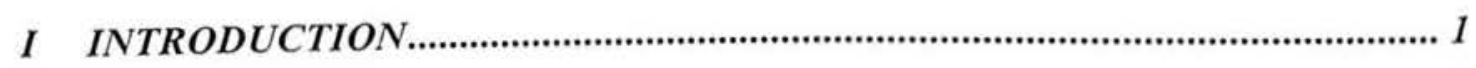

A The Contemporary Significance of the Right to Language ............................ 2

B Cultural and Linguistic Diversity in New Zealand ......................................... 4

C Exploring the Right to Language in New Zealand ......................................... 4

II THE RIGHT TO LANGUAGE ........................................................................ 5

A Sources of the Right to Language in New Zealand ....................................... 5

1 International source: article 27 of the ICCPR ......................................... 5

2 Domestic source: section 20 of the Bill of Rights Act .................................. 8

3 Protection of "native" languages: Article II of the Treaty........................ 10

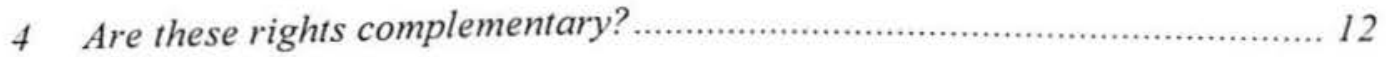

B Defining the Right to Language in the New Zealand Context ...................... 13

1 Individual versus group beneficiaries of the right to language …............. 14

2 Defining a linguistic minority .................................................... 16

3 State "denial" of the right to language ................................................. 18

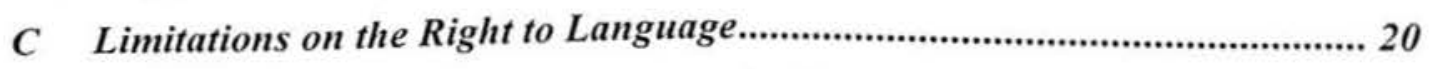

1 Limits on the right to language must be "prescribed by law".................... 22

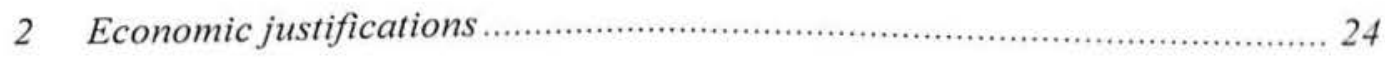

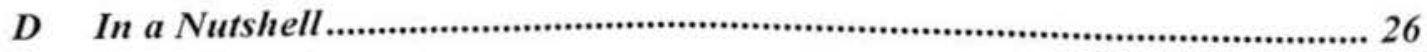

III TE REO MÄORI \& LESSONS FOR REVITALISATION................................ 26

A Māori Language - Is New Zealand Now Meeting its Obligations?.............. 26

B Moriori Language - Is New Zealand in Breach of its Obligations?............ 28

IV TWO MODES OF REVITALISING A MINORITY LANGUAGE.................. 30

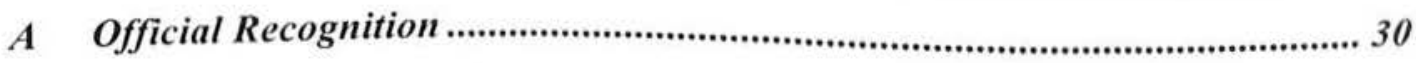

1 Different methods of official recognition ............................................. 31

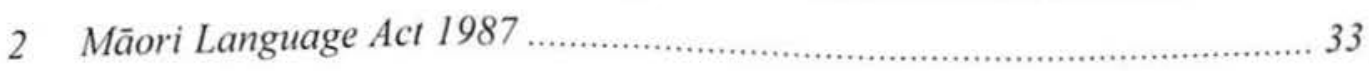

3 What could official recognition do for the Moriori language?.................... 34 


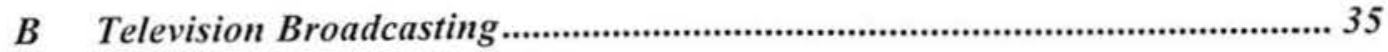

1 Mäori language television broadcasting …............................................. 36

2 Broadcasting of the Moriori language ................................................ 37

V GUIDING PRINCIPLES FOR STATE OBSERVATION ............................. 38

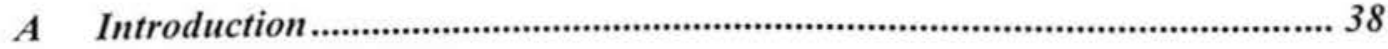

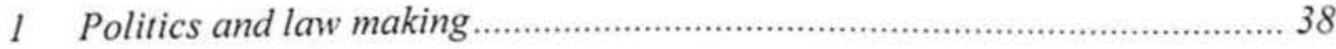

2 Principles of the Treaty of Waitangi as foundation .................................. 39

B State to be Informed about Well-being of Minority Languages................... 41

C Partnership between the State and the Minority ............................................ 44

D Active and Protective Role of the State............................................................ 46

E Access to Redress............................................................................................. 47

VI CONCLUSION - RIGHT TO LANGUAGE IN NEW ZEALAND ................... 49

A Right to Language: Three Complementary Sources...................................... 49

B Observance of the Right to Language in New Zealand ................................ 50

C Where to from here, New Zealand?.............................................................. 51

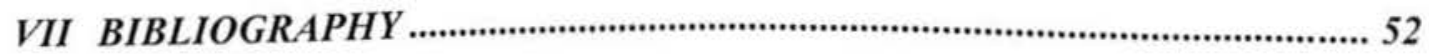

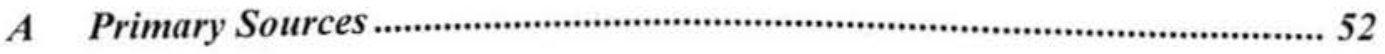

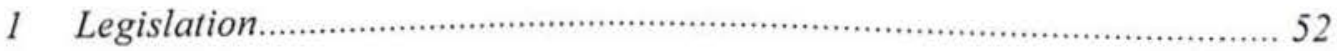

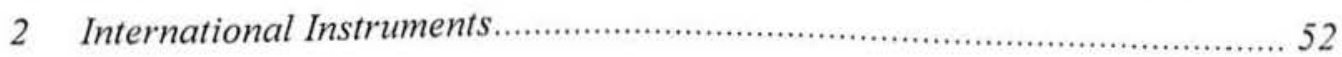

3 Cases \& Views of the UN Human Rights Committee .............................. 52

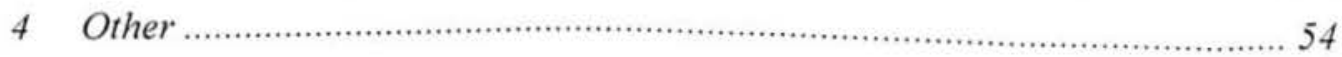

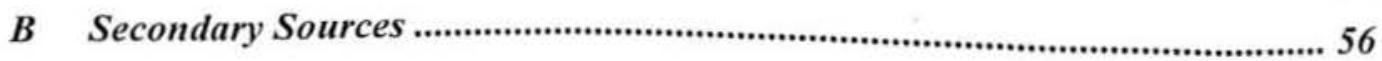

VIII SOME MĀORI \& MORIORI TERMS USED IN PAPER .......................... 58 


\section{ABSTRACT}

The right of linguistic minorities to speak their own language in community with other members of their group (the right to language) is deserving of specific attention for two reasons. Firstly, language is the currency of communication and one of the key indicia of cultural identity; and secondly, ensuring minorities have a secure place within a State is pivotal to promoting peace and stability within a nation. There are three sources of the right to language in New Zealand: the International Covenant on Civil and Political rights, the New Zealand Bill of Rights Act 1990, and the Treaty of Waitangi (for the Mãori and Moriori languages). The right to language protects against both direct action by the State to limit linguistic minorities' use of their language, and State neglect of a minority language.

This paper explores the right to language in the New Zealand context including the sources and elements of the right to language; the application of the right to the Maaori language (and what lessons can be learned from this experience for the Moriori language); and two modes of revitalisation of minority languages: official recognition and television broadcasting. The paper observes that while the steps to improve language acquisition and use of the Māori language are admirable and need to continue to secure a meaningful place for that language in New Zealand, the Moriori language is in serious jeopardy and in need of urgent attention. Finally, the paper examines whether the principles of the Treaty of Waitangi may provide sound guidance for the consideration of the place of minority languages in policy and law making in New Zealand.

The text of this paper (excluding abstract, table of contents, footnotes, and bibliography) comprises approximately 15800 words.

Human Rights - Language - Linguistic Minorities 


\title{
I INTRODUCTION
}

The right of linguistic minorities to speak their own language in community with other members of their group ${ }^{1}$ is protected as part of the right to culture and is deserving of specific attention because it is the currency of communication and one of the key indicia of identity. The right of minorities to their culture is "directed towards ensuring the survival and continued development of the cultural, religious and social identity of the minorities concerned, thus enriching the fabric of society as a whole." 2 The right to culture is also termed the "right to identity", 3 and as States struggle to define and maintain an harmonious sense of nationhood their observance of this right may well prove to be pivotal in achieving the United Nations goals of peace and stability. ${ }^{4}$

The inherent connection between language and culture is an established view. For example, Justice Hardie Boys in the 1992 Court of Appeal decision of the Mãori Council broadcasting cases ${ }^{5}$ states: $^{6}$

\begin{abstract}
It needs neither evidence nor judicial pronouncement to confirm that language lies at the heart of culture. Indeed, each is fundamental to the other. If one dies so will the other. If a language is not to die, it must be used...spoken and understood by ordinary people in their day-to-day lives... .
\end{abstract}

This position is readily reflected across not only the Mãori Council broadcasting cases ${ }^{7}$ but also in discussions of the right in academic commentary, ${ }^{8}$ and United

\footnotetext{
${ }^{1}$ For the purposes of this paper the right of linguistic minorities to speak their own language in community with other members of their group will be referred to as the "right to language".

2 United Nations Human Rights Committee "General Comment No 23" (8 April 1994) CCPR/C/21/REV.1/Add.5, para 9.

${ }^{3}$ Patrick Thornberry International Law and the Rights of Minorities (Clarendon Press, Oxford, 1991) 141.

${ }^{4}$ See for example Charter of the United Nations (26 June 1945) UKTS 1946 No. 67, Preamble and Article 1.

5 For the purposes of this paper the phrase "Mâori Council broadcasting cases" refers to: New Zealand Māori Council v Attorney-General (3 May 1991 and 29 July 1991) HC WN CP 942-88, McGechan J; New Zealand Māori Council v Attorney-General [1992] 2 NZLR 576 (CA); New Zealand Mãori Council v Attorney-General [1994] I NZLR 513 (PC); New Zealand Mãori Council v Attorney-General (29 March 1996) HC WN CP 40-96 McGechan J; and New Zealand Mäori Council v Attorney-General [1996] 3 NZLR 140 (CA).

${ }^{6}$ New Zealand Măori Council v Attorney-General [1992] 2 NZLR 576, 587 (CA) Hardie Boys J.

${ }^{7}$ See for example New Zealand Mäori Council v Attorney-General [1996] 3 NZLR 140, 168 (CA) Thomas $\mathrm{J}$ dissenting.
} 
Nations documents. ${ }^{9}$ The relationships between language and culture are also areas of study in both ethnolinguistics and sociolinguistics.

This paper seeks to examine the right to language in the New Zealand context. Specifically, how it is protected as part of the right to culture under article 27 of the International Convention on Civil and Political Rights (ICCPR); section 20 of the New Zealand Bill of Rights Act 1990 (Bill of Rights Act); and article II of the Treaty of Waitangi (the Treaty). The State's obligation to observe the right to language poses not only practical, legal, and policy challenges; but also poses challenges for traditional human rights discourse and highlights the influence political philosophies have on policy and law-making.

\section{A The Contemporary Significance of the Right to Language}

There are two "layers" to the right to language: the relationship between these layers is often fluid and poses interesting questions of its own. The right to language is, prima facie, about ensuring that an individual is able to interact with his or her minority group using his or her own language. The second level reveals that the status given to a minority language by the State not only affects how the language is viewed and used by the minority and society in general, but also affects the way minority groups participate effectively in the governance of the State (both as subjects and contributors of policies and the law). While the primary layer of the right to language is the focus of this paper, the secondary layer also receives some attention in terms of the role official recognition of language plays in revitalising a language.

\footnotetext{
${ }^{8}$ See for example Bill Piatt "Toward Domestic Recognition of a Human Right to Language" (1986) 23 Hous L Rev 885, 896; and James Fife "The Legal Framework for Indigenous Language Rights in the United States" (2005) 41 Willamentte L Rev 325, 328-329.

${ }^{9}$ See for example General Comment No 23, above n 2, para 9; and Javier Perez de Cuellar (ed) Our Creative Diversity: Report of the World Commission on Culture and Development (UNESCO, Paris, 1995) 178-182.
} 
Why does a modern State need to concern itself with the survival of minority languages; surely the natural attrition of languages is part of the ordinary course of nation development? An increasing body of literature suggests that meaningful access by a minority to their language and culture "enfranchises" minorities within the State and society. ${ }^{10}$ The loss of connection with culture and language, for example, is considered one of many complex factors that may contribute to youth suicide in New Zealand. " One of the main contributing factors to internal conflict in a State has been associated with suppression or marginalising of minority languages and cultures within a State. Often suppression of minority languages has mistakenly been pursued by States in the hope that a single language (frequently the language of the majority or a dominant minority) will "unify" the nation and bring it peace and stability. ${ }^{12}$ The treatment of minority languages within a modern State, therefore, poses significant questions for the direction, peace, and stability of a nation.

As to whether nationhood is a question with currency in New Zealand at the moment, one only has to look to recent social changes in terms of the growth in homegrown New Zealand culture: music, clothing, and design works. ${ }^{13}$ In the political context we have seen the question of our constitutional arrangements raised again in the form of an inquiry by the Constitutional Arrangements Select Committee $^{14}$ and the current Labour lead Government has nominated "national identity" as one of its three priorities for this parliamentary term. ${ }^{15}$ Meanwhile, the lead opposition party, National, was "caught out" trying to freshen up its image with a youth New Zealand "local brand" flavour. ${ }^{16}$

\footnotetext{
${ }^{10}$ Piatt, above $n 8$.

"Ministry of Health New Zealand Youth Suicide Prevention Strategy (Wellington, 1998). This has been recently superseded by the all ages strategy.

12 Adeno Addis "Cultural Integrity and Political Unity: The Politics of Language in Multilingual States" (2001) 33 Ariz. St. L.J 719, 723-726.

${ }^{13}$ See for example Ministry of Culture and Heritage Annual Report 2005 (Ministry of Culture and Heritage, Wellington, 2005) 2.

14 Constitutional Arrangements Committee "Inquiry to Review New Zealand's Existing Constitutional Arrangements" (2005) AJHR 1.24A.

15 New Zealand Government ( $48^{\text {th }}$ Parliament) "Budget 2006 Theme 3 - National Identity" (18 May 2006) Press Release.

16 See for example Colin Espiner "National's Reality" (24 July 2006) The Press Christchurch 9; and Ben Thomas and David W Young "Tories go to cool school in battle of the brands" (28 July 2006) National Business Review Auckland 13-01. The Labour Party also comes under some attack for pursuing popularist appeal campaigns.
} 


\section{B Cultural and Linguistic Diversity in New Zealand}

In many New Zealand cities and provincial towns, the changing ethnic makeup of our society seems readily apparent from our day-to-day social interactions. Tim Walton in a recent article advocating a written Constitution for New Zealand notes that: ${ }^{17}$

The 21 st century will see major cultural changes. In New Zealand, geography is slowly conquering history, and we are becoming a Pacific nation. The settlers who wanted to be "better Britons" and who still saw Britain as "home" are gone or fading. Already 25 percent of people under 15 are Mãori, and by 2021 the percentage will be more than 28 .

The Census Snapshot: Cultural Diversity ${ }^{18}$ taken from the 2001 census confirms the shifting nature of our cultural makeup. It revealed that 1 in 7 people are of Māori ethnicity (526,281 people), and a continued growth in numbers was recorded for the "traditional" New Zealand ethnicities of Asian (approximately 240,000 people) and Pacific peoples (231,801 people). ${ }^{19}$ The number of multilingual people has increased 20 per cent since 1996. Of those that spoke another language, the top five languages were: Māori (29 per cent), Samoan (14 per cent), French ( 9 per cent), Yue/Cantonese ( 7 per cent), and German ( 6 per cent). It is important to note, at least, two facts about these statistics - participants self-identify as belonging to an ethnic group, and the census does not assess the level of fluency of speakers. These statistics do, however, illustrate progressive changes to the make-up of New Zealand society.

\section{Exploring the Right to Language in New Zealand}

Clearly, the right to language has contemporary significance for New Zealand and this paper seeks to explore the right to language in the New Zealand context. The sources and elements of the right to language are established and examined in the first part of this paper. The focus of this assessment is on the impact

\footnotetext{
${ }^{17}$ Tim Walton "Get it in writing" (5-11 August 2006) New Zealand Listener Auckland 26-32.

${ }^{18}$ Statistics New Zealand Census Snapshot: Cultural Diversity <http://www.stats.govt.nz/productsand-services/Articles/census-snpsht-cult-diversity-Mar02.htm> (last accessed 23 September 2006)

${ }^{19}$ See above $\mathrm{n} 18$. The fastest growing ethnic groups recorded in 2001 were Korean $(19,026$ people), South African ( 14,889 people), Russian (3,084 people), Arab (2,856 people), Croat (2,502 people), and Iraqi $(2,145$ people). There is also an increase in the number of New Zealand residents who were not born in New Zealand.
} 
of neglect of a language by the State for a linguistic minority, rather than the impact of prohibitive policy or laws on an individual. The second part focuses on the New Zealand's observance of the right in relation to the Māori and Moriori languages. Part Three of this paper examines two modes of revitalisation of minority languages: official recognition and television broadcasting and looks at and what lessons can be learned from the Māori experience to assist in revitalising the Moriori language. Finally, the paper discusses whether the principles of the Treaty may provide sound guidance for the consideration of the place of minority languages in policy and law making in New Zealand.

\section{THE RIGHT TO LANGUAGE}

The right of linguistic minorities to speak their own language in community with other members of their group (or "the right to language") has three sources in New Zealand: it is protected as part of to the right culture under article 27 of the ICCPR; section 20 of the Bill of Rights Act; and the Mãori language (and arguably Moriori language too) is also protected under article II of the Treaty.

While there is a body of jurisprudence surrounding the right to language under the Treaty by virtue of the Mäori Council broadcasting cases and the Te Reo Report; ${ }^{20}$ there is limited case law surrounding the right to language under the Bill of Rights Act and the ICCPR.

This section summarises the three sources of the right to language applicable in the New Zealand context, canvases the elements of the right, and potential limitations on the right.

\section{A Sources of the Right to Language in New Zealand}

\section{International source: article 27 of the ICCPR}

New Zealand ratified the ICCPR in 1978 and article 27 of the ICCPR provides that every State that has a minority must ensure that persons belonging to a linguistic minority shall not be denied the right, in community with other members of their group, to use their own language. ${ }^{21}$

\footnotetext{
${ }^{20}$ Waitangi Tribunal Te Reo Mãori Claim: WAl II (Department of Justice, Wellington, 1986) para 6.1 .21 .

${ }_{21}$ International Covenant on Civil and Political Rights (19 December 1966) 999 UNTS 171, art 27 states: "In those States in which ethnic, religious or linguistic minorities exist, persons belonging to
} 
Thornberry's seminal text on the rights of minorities, International Law and the Rights of Minorities, provides a comprehensive discussion and analysis of article 27 of the ICCPR, including the genesis of the right, its predecessors, and observance of the right at the international level. Thornberry embarks on his discussion of the history of article 27 by noting that the climate in which this right arose was one in which: "the United Nations could not remain indifferent to the fate of minorities.",22 In relation to the right to language, Thornberry notes Scott's discussion about the fact that there isn't a universal rule for resolving language problems but that observing language rights are the corner stone to domestic peace, ${ }^{23}$ and goes on to comment: ${ }^{24}$

Apart from policies of linguistic suppression, minority languages may be disadvantaged in various ways. Great controversies are caused by such questions as the official status of languages and, in consequence, their use in administration and before the courts, public educational institutions, and in the mass media.

Article 27 of the ICCPR is generally recognised as the modern primary legal source of the right to language and this right, frequently as part of the right to culture, has been recognised in several United Nations instruments including: the Declaration on the Rights of Persons Belonging to National or Ethnic, Religious and Linguistic Minorities (the Declaration on the Rights of Minorities); ${ }^{25}$ Indigenous and Tribal Peoples Convention 1989 (No 169); ${ }^{26}$ International Covenant on Economic,

such minorities shall not be denied the right, in community with the other members of their group, to enjoy their own culture, to profess and practice their own religion, or to use their own language."

22 Thornberry, above n 3,149 .

23 Thornberry, above n 3, 197 quoting from Scott "Language Rights and Language Policy in Canada" (1971) 4 Manitoba Law Journal 243, 247-248.

${ }_{24}^{4}$ Thornberry, above n $3,197$.

${ }^{25}$ Declaration on the Rights of Persons Belonging to National or Ethnic, Religious and Linguistic Minorities (18 December 1992) A/RES/47/135.

26 See for example Indigenous and Tribal Peoples Convention No 169 (27 June 1989) $\mathrm{ST} / \mathrm{HR} / 1 /$ Rev.6(Vol.1/Part 1), art 4, 5, and 28. This Convention was adopted by the General Conference of the International Labour Organisation at its seventy-sixth session and entered into force on 5 September 1991. 
Social, and Cultural Rights; ${ }^{27}$ and the Draft United Nations Declaration on the Rights of Indigenous Peoples (Draft Declaration). ${ }^{28}$

The Declaration on the Rights of Minorities refers to article 27 of the ICCPR in its preamble and notes that the UN has an "important role to play in regarding the protection of minorities." This Declaration requires States to protect the existence of linguistic identity (article 1), enable minorities to use their language and have effective participation in decisions affecting the enjoyment of that right without discrimination (for example, articles 2 and 4(1)), and create favourable conditions to develop the language and learn the "mother tongue" (article 4). The Indigenous and Tribal Peoples Convention sets out similar protections for indigenous peoples and frames the right in terms of requiring the State to take measures to "preserve and promote the development and practice of indigenous languages of the peoples concerned." 29

Interestingly, the Draft UN Declaration on the Rights of Indigenous Peoples proposes, in addition to these sorts of protection, a requirement to enable indigenous peoples to have the right to establish their own media in their own language while having equal access to all forms of non-indigenous media. ${ }^{30}$ Further, it proposes that States take "effective measures to ensure that State-owned media duly reflect indigenous cultural diversity."

The United Nations Human Rights Committee's (the UN Committee) jurisprudence around linguistic minorities under article 27 of the ICCPR is somewhat dissatisfying because it skirts around the issue of focus in this paper: neglect of a minority language. ${ }^{32}$ It does reveal, however, that the focus of the right is on community use of the language, and not on the ability for the language to be

\footnotetext{
${ }^{27}$ International Covenant on Economic, Social, and Cultural Rights (16 December 1966) 993 UNTS 3 , art 15.

${ }^{28}$ See for example Draft United Nations Declaration on the Rights of Indigenous Peoples (UN SubCommission on Prevention of Discrimination and Protection of Minorities, 1994) E/CN.4/Sub.2/1994/56 art 14, 15, and 17.

${ }^{29}$ Indigenous and Tribal Peoples Convention No 169, above n 26, art 28(3).

${ }^{30}$ Draft Declaration on the Rights of Indigenous Peoples, above n 28, art 17.

${ }^{31}$ Draft Declaration on the Rights of Indigenous Peoples, above n 28, art 17.

${ }^{32}$ See for example Ballentyne, Davidson \& McIntyre v Canada (5 May 1993) UN Human Rights Committee CCPR/C/47/D/385/1989; Cadoret \& Le Bihan v France (11 April 1991) UN Human Rights Committee CCPR/C/41/D/323/1988; Guesdon v France (23 August 1990) UN Human Rights Committee CCPR/C/39/D/219/1986; Barzhig v France (6 May 1991) UN Human Rights Committee CCPR/C/41/D/327/1988and Diergaardt $v$ Nambia (6 September 2000) UN Human Rights Committee CCPR/C/69/D/760/1997.
} 
used between the minority and the State. ${ }^{33}$ Although no finding under article 27 was made in Diergaardt $v$ Nambia, the UN Committee did find discrimination under article 26 for failure to allow officials to respond in languages other than the official language. ${ }^{34}$ Further, the individual opinion in Diergaardt of Abdalfattah Amor (dissenting) notes that it is the ability for community use of the language that is protected by article 27; this discussion does not, however, capture situations of neglect bought about by State inaction. ${ }^{35}$

Mahuika v New Zealand is a Communication under article 27 of the ICCPR in which the claimants contested the Treaty of Waitangi (Fisheries Claim) Act and claimed that the Government's actions were "threatening their way of life and the culture of their tribes, in violation of article 27 of the Covenant." 36 The UN Committee considered that the Government had undertaken as fair a process as they could and did not find in favour of the claimants, but emphasised in paragraph 9.9 that "measures affecting the economic activities of Māori must be carried out in a way that the authors continue to enjoy their culture, and profess and practice their religion in community with other members of their group". This Communication restates earlier jurisprudence around the right to culture, and notes that the application of the right cannot be "in abstracto", that the situation has bearing on the outcome and the actions the State must undertake.

\section{Domestic source: section 20 of the Bill of Rights Act}

According to the preamble of the Bill of Rights Act it was enacted to affirm New Zealand's commitment to the ICCPR, and to "affirm, protect, and promote human rights and fundamental freedoms in New Zealand". The Bill of Rights Act contains a range of civil and political rights, and some procedural provisions that determine the application of the Act. The text A Bill of Rights for New Zealand: A White Paper (White Paper) states, in the introduction by the Rt Hon Sir Geoffrey Palmer (then Minister of Justice), that: "A Bill of Rights will provide greater

\footnotetext{
${ }^{33}$ See for example Cadoret \& Le Bihan v France, above n 32, paras 4.3, 4.9, and 5.3; Guesdon v France, above n 32, paras 5.6, 6.5, 7.3, and 10.4; and Barzhig v France, above n 32, paras 4.8, 5.2 and 5.7.

${ }^{34}$ Diergaardt $v$ Nambia, above n 32, para 10.6-10.10.

${ }^{35}$ Diergaardt $v$ Nambia, above n 32, para 10.6-10.10.

${ }^{36}$ Mahuika v New Zealand (15 November 2000) UN Human Rights Committee $\mathrm{CCPR} / \mathrm{C} / 70 / \mathrm{D} / 547 / 1993$, paras 6.1 and 6.2 .
} 
protection for the fundamental rights and freedoms vital to survival of New Zealand's democratic and multicultural society." ${ }^{37}$

Section 20 of the Bill of Rights Act provides that persons belonging to a linguistic minority shall not be denied the right, in community with other members of their group, to use their own language. ${ }^{38}$ Prior to the enactment of the Bill of Rights Act there was no legislative recognition of a general right to language, although the Waitangi Tribunal (the Tribunal) in the Te Reo Mãori Claim (Te Reo Report $)^{39}$ had declared that article II of the Treaty conferred a protection on the Mãori language and the Māori Language Act 1987 had been passed.

The right to language, as part of section 20 of the Bill of Rights Act, as proposed by the White Paper foresaw it as a narrow right: ${ }^{40}$

\begin{abstract}
What [section 20] is aimed at is oppressive government action which would pursue a policy of cultural confortinity by remering the rights of minoritics to enjoy those things which go to the heart of their identity - their language, culture, and religion. It should be noted too, that [section 20] together with [section 15] not only guarantee the right of members of a minority group to practice etc their religion or belief individually and in private, but also in community with other members of the group and in public.
\end{abstract}

There appears to have been little debate around the effect of section 20 of the Bill of Rights Act; ${ }^{41}$ this is not surprising, perhaps, given the narrow description in the White Paper. ${ }^{42}$ This narrow approach to the right will be discussed later, but it is timely to note that the White Paper description is now at odds with ICCPR jurisprudence around the right to culture, and the general approach taken to interpreting rights under the Bill of Rights Act. There is limited case law around section 20 of the Bill of Rights Act, and no specific cases on the language

\footnotetext{
${ }^{37}$ Department of Justice A Bill of Rights for New Zealand: A White Paper (Government Printer, Wellington, 1985) 5.

${ }^{38}$ New Zealand Bill of Rights Act 1990, s 20 states: "A person who belongs to an ethnic, religious, or linguistic minority in New Zealand shall not be denied the right, in community with other members of that minority, to enjoy the culture, to profess and practise the religion, or to use the language, of that minority."

${ }^{39}$ Te Reo Report, above n 20.

White Paper, above n 37 , para 10.83.

${ }^{41}$ The rights of minorities were occasionally referred to during the Parliamentary debates as a way of poking fun at the Opposition.

42 (10 October 1989) 502 NZPD 13047-13048, 13051-13053, and 13056-13057; (14 August 1990) 510 NZPD 3450; and (21 August 1990) 510 NZPD 3763-3765.
} 
component of the right. ${ }^{43}$ The Court of Appeal decision in Mendelssohn v AttorneyGeneral $^{44}$ is about religious minority rights and while the case offered some commentary on section 20 of the Bill of Rights Act the commentary diverges from international jurisprudence and Māori Council broadcasting cases.

\section{Protection of "native" languages: Article II of the Treaty}

New Zealand has an additional protection for the Māori language, and arguably other "native" languages, under article II of the Treaty. In summary, article II of the English text of the Treaty provides that the Crown "confirms and guarantees...the full exclusive and undisturbed possession of...other properties". The Mãori text uses the word "taonga" instead of "other properties", and "taonga" is generally translated as "treasure" or "valued possession". Māori language and culture are considered "taonga"; therefore, in reading these two texts together the Tribunal found that the Crown had an obligation to protect and promote the Mãori language. ${ }^{45}$

The first authoritative declaration of this right was in 1986 by the Tribunal in the Te Reo Report. ${ }^{46}$ Prior to the Te Reo Report there had been some attempts for the Mãori language to receive legislative recognition in the form of petitioning Parliament (in 1972 the Māori Language Petition was signed by 30,000 people), ${ }^{47}$ and bills introduced to the House of Representatives (the House) seeking legal recognition or promotion of the Māori language. ${ }^{48}$ The Tribunal, in contemplating the claim, canvassed three pivotal dimensions to the right to language under article II of the Treaty: the scope of the term "taonga", the legitimacy of a joint reading of the two texts, and the nature of the guarantee. ${ }^{49}$

The scope of "taonga" in article II of the Treaty had been the subject of previous consideration by the Tribunal that had found that it encompassed both the

\footnotetext{
${ }^{43}$ While some judgments refer to section 20 of the Bill of Rights Act, they very rarely include discussion of the right itself. See for example Manukau v Attorney-General [2000] NZAR 621, para 11 Chambers J; Keelan v Peach [2002] NZFLR 481, para 21 (HC) Paterson J; Fenwick v Trustees of Nga Kaihautu o Te Arawa Exeuctive Council (13 April 2006) HC ROT CIV-2004-463-847, paras 9496 Allan J; and Ngati Apa ki te Waiponamu Trust v R [2000] 2 NZLR 659, paras 82-84 (CA) Elias CJ. ${ }^{44}$ Mendelssohn v Attorney-General [1999] 2 NZLR 268 (CA).

${ }^{45}$ Te Reo Report, above n 20 , ch 4.2 .

${ }^{46}$ Te Reo Report, above n 20.

${ }^{47}$ Archives New Zealand <www.archives.govt.nz/exhibitions/pasteshibitians/tereo/ 1970_eng. php> (last accessed 1 September 2006).

48 Clause 51 of the Mãori Affairs Amendment Bill 1974; Mãori Language Bill 1980; and Mãori Language Bill 1983.

${ }^{49}$ Te Reo Report, above n 20, para 4.2.4.
} 
tangible and intangible things that are "highly prized" or "valued" by Māori. ${ }^{50}$ In considering whether the Mãori language was "taonga", the Tribunal stated: "It is plain that the language is an essential part of the culture and must be regarded as 'a valued possession'." 51

Section 5(2) of the Treaty of Waitangi Act 1975 provides for the Tribunal to have regard to both texts of the Treaty in deciding on issues raised by the differences between them: it provides that the Tribunal "shall have exclusive authority to determine the meaning and effect of the Treaty as embodied in the two texts". Bearing this responsibility in mind, the Tribunal determined that the broader interpretation of "taonga" from the Māori text was the proper interpretation and noted that it had applied ordinary legal principles relating to treaties to draw this conclusion. $^{52}$

The English text uses the term 'guarantee' in relation to the rights in article II, and the Tribunal accepted submissions from the New Zealand Section of International Commission of Jurists that the term denoted a proactive obligation or affirmative action. ${ }^{53}$ Finally, the Tribunal noted that not only did the Treaty protect the Mãori language but: ${ }^{54}$

We question whether the principles and broad objectives of the Treaty can ever be achieved if there is not a recognised place for the language of one of the partners to the Treaty. In the Mãori perspective the place of the language in the life of the nation is indicative of the place of the people.

Although the right has not been directly and explicitly incorporated into domestic legislation the Crown appears to have readily accepted this construction of the right to language because it acted on the Tribunal's finding that the Crown had breached article II of the Treaty in respect of the Māori language. The Crown did not challenge this formulation of the obligation in the Mäori Council broadcasting cases in which Māori challenged the Crown proposals to transfer, and later the sale,

\footnotetext{
${ }^{50}$ Reference is made in the Te Reo Report, above n 20, (para 4.23) to the Tribunal's previous findings of Kaituna River Finding, and Motunui Finding.

${ }^{51}$ Te Reo Report, above n 20, ch 4.2.

${ }^{52}$ Te Reo Report, above n 20, paras 4.2.5-4.2.6.

${ }_{53}^{5}$ Te Reo Report, above n 20, paras 4.2.7 - 4.2.8.

${ }^{34}$ Te Reo Report, above n 20, para 4.2.8.
} 
of radio and television broadcasting assets by the Crown. ${ }^{55}$ New Zealand courts, including the Privy Council, have endorsed this formulation of the right and frequently noted the Crown's acceptance of its responsibilities towards the Māori language under the Treaty. The Crown introduced, days before the release of the $T e$ Reo Report, the Māori Language Bill that ulitmately declared Māori to be an official language of New Zealand. The ongoing commitment of the Crown is also reflected in the recent enactment of the Māori Television Service (Te Aratuku Whakaata Irirangi Māori) Act 2003 (Māori Television Act).

In 2001 the Tribunal, when considering the Moriori and Ngati Mutunga claims in the Chatham Islands, found that the Treaty was not restricted to Mãori as it refers to "native peoples" and, therefore, Moriori were entitled to its protection in their own right. ${ }^{56}$ Therefore, arguably, the protection in article II for language may also extend to the Moriori language especially given the proximity of meaning between the Maori and Moriori languages (discussed later).

\section{Are these rights complementary?}

In answer to the question of whether these rights are fitting for comparison, the author notes that on a superficial level these rights to language differ because the Treaty right to language has been framed as a guarantee and targets a specific minority group - Māori or native peoples; whereas the Bill of Rights Act and ICCPR require that a State must not deny the right to language and frame it as an individual, rather than collective, right. However, these three iterations of the right to language, while different in form, all represent a commitment by the State to protect the language and culture of minorities. Further, they are all influenced by treaty interpretation techniques, and provide for the right at a general principled level (that is, they do not specify how the right to language is to be observed).

In examining these expositions of the right to language and identifying guiding principles, the differences between the form of the right become less pivotal. The precedent value established for State action in respect of the right to language protected by the Treaty provides a unique opportunity to examine whether the lessons learned in relation to the Māori language may be transferable and assist in

\footnotetext{
55 See for example New Zealand Māori Council v Attorney-General (3 May 1991) HC WN CP $942-$
88,4 McGechan J.

56 Waitangi Tribunal Rekohu: A Report on Moriori and Ngati Mutunga Claims in the Chatham Islands: Wai 64 (Legislation Direct, Wellington, 2001) paras 2.1-2.10 and 14.1 (Rekohu Report).
} 
interpreting the nature of the State's obligations for observing the right to language as affirmed under both the Bill of Rights Act and the ICCPR.

\section{B Defining the Right to Language in the New Zealand Context}

The core elements of the right to language centre on who can claim the protection of the right, what constitutes a linguistic minority, and what constitutes "denial" of the right by the State.

That human rights call for a generous interpretation is little contested. In the New Zealand context, the 1992 Court of Appeal decision of Ministry of Transport $\mathrm{v}$ Noort (Noort) wholeheartedly endorsed this approach, ${ }^{57}$ Justice Gault summarises the approach at page 292:

The fundamental rights affirmed in the Bill of Rights Act are to be given full effect and are not to be narrowly construed. Its provisions are to be construed to ensure its objects of protecting and promoting human rights and fundamental freedoms. It is a statute, not an entrenched constitutional document, but it is couched in broad terms requiring interpretation appropriate to those objects.

This approach is consistent with interpretation of the right to language under both the ICCPR and the Treaty. ${ }^{58}$ Justice McGechan, in the Māori Council broadcasting cases, also emphasised the importance of observing the spirit of the Treaty, and the necessity of acting with "utmost good faith, fairly, and reasonably." 59 This principle is also analogous to that of pacta sunt servunda or the good faith principle under which States must observe their international treaty obligations. ${ }^{60}$

Human rights discourse has constructed interpretive models to assist with defining the scope of human rights. Examining the right to language bought into sharper focus questions about the sustainability of rights discourses which frame human rights as binary oppositions, particularly: positive versus negative rights; individual versus group rights; rights as aspirational goals versus minimum guarantees; and rights as having universal versus relative application. Aspects of

\footnotetext{
${ }^{57}$ Ministry of Transport v Noort (Police v Curran) [1992] 3 NZLR 260, 268-271 (CA) Cooke P; $277-$ 279 (CA) Richardson J; 286 (CA) Hardie-Boys J; and 292 (CA) Gault J.

58 See for example General Comment No 23, above n 2, para 6.1 and New Zealand Māori Council v Attorney-General, above n 55, 21 (HC) McGechan J.

${ }^{59}$ New Zealand Mäori Council v Attorney-General, above n 55, 21 (HC) McGechan J.

${ }^{60}$ See for example Vienna Convention on the Law of Treaties (22 May 1969) 1155 UNTS 331, art 26.
} 
this discourse and how they relate to the right to language is included in the discussion below.

\section{Individual versus group beneficiaries of the right to language}

The right to language focuses on the ability for an individual to use their language in community with other members of the group. Human rights are traditionally viewed as attaching to the "individual", ${ }^{61}$ yet the right to culture refers to the ability for the language to be practiced in community with other members of the group. Justice Thomas in the Court of Appeal decision in Quilter v AttorneyGeneral described these sorts of rights as having a "relational aspect" because "[w]hilst the right may apply to an individual, it is that individual's relationship with another person which gives rise to the right." 62

In relation to language, a medium of communication, the well-being of the group is inextricably connected to an individual's ability to exercise the right. To this end the UN Committee has observed that although this is an individual right it depends, “... in turn on the ability of the minority group to maintain its culture, language or religion." 63 One of the reasons for framing it as an individual right appears to have been to prevent minorities from gaining international personality or mobilising against the State to force cession. ${ }^{64}$ Further, a general suspicion of group rights seems to centre around the concerns about how the groups are mandated (that is, how is authority for a delegation determined), or that some members of a minority group may wish to enforce the right against other members of their group. ${ }^{65}$

In terms of exercising this right the question of whether this right is conferred on an individual or a group or community may be largely negligible in the New Zealand context. The Treaty bestows the right to language on Māori (and native peoples within New Zealand) and, although this point has yet to be determined under the Bill of Rights Act, the UN Committee has considered this question in respect of a New Zealand communication and observed that: ${ }^{66}$

\footnotetext{
${ }^{61}$ See for example Paul Rishworth (ed) The New Zealand Bill of Rights (Oxford University Press, 2002) 399-400; Mahuika $v$ New Zealand, above n 36, para 9.2; General Comment No 23, above n 2, para 5.1; and Thornberry, above n 3, 173.

${ }_{63}^{62}$ Quilter v Attorney-General [1998] 1 NZLR 523, 535-536 (CA) Thomas J.

${ }_{63}$ General Comment No 23, above n 2, para 6.2.

${ }^{64}$ Thornberry, above n 3, 173-175.

${ }_{66}^{65}$ See for example Thornberry, above n 3, ch. 17; and Rishworth, above n 61, 399-400.

${ }^{66}$ Mahuika v New Zealand, above n 36, para 9.2 (emphasis added).
} 
... [T] he Optional Protocol provides a procedure under which individuals can claim that their individual rights have been violated. ... As shown by the Committee's jurisprudence, there is no objection to a group of individuals, who claim to be commonly affected, to submit a communication about alleged breaches of these rights.

Pragmatically, there can be little debate that suppression of an individual's ability to use their language in community with others from their group (for example, prohibiting it in the school playground or other public arenas) would engage the right to language. The right to language in this context is viewed as setting a minimum standard, against which a State would have to have compelling arguments to justify any limitation. However, the picture is less clear in situations where neglect has resulted in deterioration of the group's ability to use their own language (which in turn affects an individual's ability to access their language) and the language requires revitalisation. Based on the approach taken in the Mâori Council broadcasting cases and several of the UN Committee decisions around article 27, it would seem that group language revitalisation is encompassed by the right and would be approached on the basis of "progressive realisation" (that is, a State must take steps to assist in the revitalisation of a vulnerable minority language).

This view appears to be at odds with the traditional human rights discourse about the distinction between first generation rights (civil and political rights) as minimum guarantees, and second generation rights (economic, social, and cultural rights) as rights requiring progressive realisation. ${ }^{67}$ In reality, domestic and international observance of the right to culture has seen a step away from this traditional human rights discourse. The right to language is contained in the ICCPR placing it firmly as a first generation right yet much of the commentary and jurisprudence frames the right in terms of progressive realisation where group survival is in jeopardy. ${ }^{68}$ This seems largely due to the economic constraints on a State that may limit the level of ongoing State intervention. ${ }^{69}$ This influences not only the manner in which the State may observe the right, but also the severity of

\footnotetext{
${ }^{67}$ See for example D J Harris (ed) Cases and Materials on International Law (Sweet \& Maxwell, London, 1998) 625.

${ }^{68}$ See generally Lovelace $v$ Canada $(30$ July 1981) UN Human Rights Committee CCPR/C/13/D/24/1977; and Kitok v Sweden (10 August 1988) UN Human Rights Committee CCPR/C/33/D/197/1985.

${ }^{69}$ See for example New Zealand Mäori Council v Attorney-General [1994] I NZLR 513, 517 (PC)

Lord Woolf for the Judicial Committee; and Addis, above n 12, 774-777
} 
any assessment of limitations the State may place on the right (that is, greater consideration may be shown where the right is being realised progressively for a vulnerable minority language).

Why is this distinction between minimum standard/individual and progressive realisation/collective important? In a word, remedies. A New Zealand court cannot strike down legislation or policy that is inconsistent with the Treaty or the Bill of Rights Act; ${ }^{70}$ however, the choices for redress are not legislatively constrained. Remedies are generally targeted towards "repairing" the breach. Compensation may be acceptable in situations where the breach is discrete; namely where impact is limited to an individual or a small group of individuals. Compensation, however, is unlikely to be a meaningful remedy where a minority group's language has been negatively affected by ongoing neglect. The outcome of the Māori Council broadcasting cases demonstrates that an ongoing breach needs to be remedied through policy or legislative action. The nature of the remedies available is likely to have a flow on effect to how State's observe the right by establishing the permissible parameters of State action.

\section{Defining a linguistic minority}

In simple terms, a linguistic minority is a community of people who share a common language and are numerically smaller to the majority group inhabiting a State's territory. It is worth noting that a linguistic minority is often, though not always, likely to share a common cultural heritage. The concept of human rights being "universal" is now widely accepted and sees human rights attaching to all human beings simply by virtue of a person being a human being regardless of the extent to which a State recognises the rights. While this is an established principle, the development of the right to culture reveals a more complex situation. ${ }^{71}$ The question of what constitutes a "minority" was viewed in strikingly different ways during the development of the article 27 right in the ICCPR. Many States viewed a "minority" for this right as a numerically smaller group of people with a common language, religion, or ethnicity within that State. Some States, however, saw the right as being relativist and applying only to the "traditional" minorities of the European nations rather than to developing nations (that is, a right responding to the

\footnotetext{
${ }_{71}^{70}$ New Zealand Bill of Rights Act 1990, s 4.

${ }^{71}$ See generally Thornberry, above $\mathrm{n} 3$, ch 15 and 16.
} 
persecution of Jews during World War II or other States with minority "problems"); ${ }^{72}$ while other States do not consider they have "minorities" per se (for example, claiming that all peoples in the territory are bound by a common overarching culture). ${ }^{73}$

The UN Committee, to ensure that an arbitrary standard isn't used for defining whether minorities exist within a State's borders, determined that the question of what is a "minority" as a factual inquiry and to be established by objective criteria. ${ }^{74}$ Identifying linguistic minorities should, according to The New Zealand Bill of Rights (Rishworth), be straightforward in New Zealand. In the case of both the Māori language and New Zealand Sign Language the Crown recognised the languages as official languages, and both Māori and the Deaf communities are numerically smaller in New Zealand. ${ }^{75}$

A more interesting question arises in relation to the Moriori language; is it a separate language or is it a dialect of the Māori language given it's close relationship with the Māori language? The pragmatic approach would suggest that although the Moriori language is closely related to the Māori language ${ }^{76}$ Moriori have been recognised as being culturally distinct ${ }^{77}$ and their language has developed different pronunciation and idioms. Therefore, Moriori should be treated as a distinct linguistic minority.

A broad and purposive interpretation of the right to language would suggest that a person belongs to a linguistic minority even where they lack sufficient language proficiency to converse freely in the language, especially where that lack of proficiency is due to the erosion of the well-being of the language within that minority group.

\footnotetext{
${ }^{72}$ For example representatives from the following countries did not consider it relevant to their state: Australia, Spain, Liberia, Guinea, Mali, Ghana, and Upper Volta.

${ }^{73}$ Addis, above n 12, notes that France did not consider it had regional or minority languages when signing the European Charter for such rights.

${ }_{74}$ General Comment No 23, above n 2, para 5.2. See also Lovelace v Canada, above n 68, paras 14 and 17 in which the Committee considered that although the Canadian statutory definition precluded Lovelace's membership, she remained ethnically a Maliseet Indian.

${ }^{75}$ Rishworth, above n 61, 405-406, and 408.

${ }_{77}^{76}$ Michael King A Land Apart (Random Century New Zealand Ltd, Hong Kong, 1990) 11.

${ }^{77}$ Rekohu Report, above n 56.
} 


\section{State "denial" of the right to language}

As discussed above, all three of these formulations of the right to language place an obligation on the State to observe the right both in terms of individual enjoyment of the right, and collective enjoyment where a language is in jeopardy. The state of the Māori language was carefully examined in the Te Reo Report and the Mãori Council broadcasting cases - both found that the Mãori language was in a serious state of decline, ${ }^{78}$ and adopted a factually-based assessment based on three main factors: ${ }^{79}$

- the current usage of the minority language;

- whether the language is in a vulnerable state;

- the degree to which the State is culpable for the condition of the language.

In terms of what type of behaviour may result in State culpability, the right to language captures all behaviour (acts, omissions, and neglect) of the State that results in the denial of the right to language, not just direct acts that impact on the right. Laws and government policies that seek to suppress a language or unnecessarily restrict a person or community's ability to converse in their own language clearly falls within the ambit of the right to language as an individual who is being denied the ability to use their language in community with others. Failing to include one or more minority languages in policies and laws seeking to promote or facilitate language use (eg: public broadcasting or language education curriculum policies) is also likely to fall within the ambit of the right. ${ }^{80}$ For the same reasons omissions are caught, so too must neglect of minority languages, by implication, be captured by the right where such neglect results in diminished opportunity for individuals and communities to use their own language.

This issue of the extent to which the right captures omissions and neglect is connected to the broader question of whether the right to language is a "negative" right or a "positive" right. ${ }^{81}$ Article II of the Treaty has been interpreted as placing a

\footnotetext{
${ }^{78}$ See generally New Zealand Māori Council v Attorney-General, above n 69; and Te Reo Report, above n 20, ch 3.3 .

${ }^{79}$ See for example New Zealand Mäori Council v Attorney-General, above n 69, 517-518 (PC) Lord Woolf for the Judicial Committee.

${ }^{80}$ See for example Andrew Butler \& Petra Butler The New Zealand Bill of Rights Act: A Commentary (LexisNexis NZ Limited, Wellington, 2005) para 5.2.10 (the Butlers' Commentary).

${ }^{81}$ See for example Rishworth, above n 61, 403-405. See generally Alexander B Blades "Article 27 of the International Covenant of Civil and Political Rights: A Case Study on Implementation on Civil
} 
positive and active obligation on the Crown; however, section 20 of the Bill of Rights Act and article 27 of the ICCPR are generally heralded as negative rights (that is, the State is not to interfere with individuals' ability to exercise their right to language). ${ }^{82}$ In Mendelssohn v Attorney-General the Court of Appeal took a surprisingly narrow approach to the right to culture: ${ }^{83}$

\begin{abstract}
The short answer ... is that in their essence those provisions do no impose positive duties on the state, at least in any sense relevant to this case. Rather they affirm freedoms of the individual which the [S]tate is not to breach. The very nature of these rights and freedoms means that they are freedoms from [S]tate interference. ... The freedoms in issue are in general within the category often referred to as negative freedoms, to use one part of Isaiah Berlin's famous categorisation (Two concepts of Liberty (1958)....)."
\end{abstract}

This is a surprising (and disappointing) approach because it seems incompatible with early declarations by the Court of Appeal supporting a generous interpretative approach to human rights. Further, it appears inconsistent with the UN Committee's approach to the right that acknowledges that although the right is negatively framed it requires positive State action: ${ }^{84}$

\begin{abstract}
Although article 27 is expressed in negative terms, that article, nevertheless, does recognise the existence of a 'right' and requires that it shall not be denied. Consequently, a State party is under an obligation to ensure that the existence and the exercise of this right are protected against their denial or violation. Positive measures of protection are, therefore, required not only against the acts of the State party itself, whether through its legislative, judicial or administrative authorities, but also against the acts of other persons with the State party.
\end{abstract}

It is bizarre and contradictory to the generous approach for interpreting human rights to not capture situations where a State has neglected minority languages: doing nothing in some situations may be tantamount to actively suppressing minority

\footnotetext{
and Human Rights in New Zealand" [1994] 1 CNLR I. Blades examines the positive and negative interpretations of the right advocating a positive interpretation, and goes on to discuss the implementation of the Treaty (and whether it can be done through article 27).

${ }^{82}$ See for example Mendelssohn above n 44, para 14 per Keith J for the Court; Rishworth, above n 61, 404; and White Paper, above n 37, para 10.83.

${ }^{83}$ Mendelssohn, above $\mathrm{n} 44$, para 14 Keith $\mathrm{J}$ for the Court.

${ }^{84}$ General Comment No 23, above n 2, para 6.1
} 
languages. Further, this approach seems overly simplistic and fails to take into account section 3 of the Bill of Rights Act. ${ }^{85}$ Section 3 of the Bill of Rights Act, despite referring to 'acts done' by the State, provides that the Bill of Rights Act applies to all acts and omissions. The Butlers' Commentary acknowledges this principle of interpretation: "while [section] 3 of [Bill of Rights Act] refers to "acts done", omissions to do things are also, in principle, covered by [section] 3". 86

For the reasons above, I respectfully disagree with the general observations and narrow interpretation attributed to section 20 of the Bill of Rights Act by the Mendelssohn decision, and consider that it is not in keeping with the general interpretation principles for human rights. The situation in Mendelssohn is, however, distinguishable on its facts from observance of the right to language. The plaintiff in Mendelssohn was claiming that the State owed him a positive duty to intervene on his behalf with his commune; this was not a situation where the individual was being denied the right to practise their religion by action or inaction of the State - that individual's exclusion resulted from the community's choice. While recognising that this statement is somewhat controversial, a community is entitled to manage (consistently with the law) its membership without interference from the State.

\section{Limitations on the Right to Language}

The right to language, like the right to culture, is not absolute. Justice Richardson in Noort provides a useful summary, noting that limitation clauses reflect: ${ }^{87}$

... [T] he reality that rights do not exist in a vacuum, that they may be modified in the public interest to take account of the rights of others and of the interests of the while community. Equally clearly s 5 [of the Bill of Rights Act] guards those rights by insisting that they may be regarded as modified only where the stringent tests laid down are met.

\footnotetext{
${ }^{85}$ Section 3 of the New Zealand Bill of Rights Act 1990 is broader than core State agencies and states: "This Bill of Rights applies only to acts done (a) By the legislative, executive, or judicial branches of the government of New Zealand; or (b) By any person or body in the performance of any public function, power, or duty conferred or imposed on that person or body by or pursuant to law."

${ }^{86}$ Butlers' Commentary, above n 80, para 5.2.10.

${ }^{87}$ Noort, above n 57, 283 Richardson J.
} 
Article 27 of the ICCPR is not subject to a specific limitation provision and the UN Committee has determined that the right is not to be assessed by reference to a "margin of appreciation". 88 The UN Committee does, however, recognise that "measures that have a certain limited impact on the way of life of persons belonging to a minority will not necessarily amount to a denial of the right". 89 This approach appears to set the threshold higher for whether or not a breach of the right has occurred; suggesting that the measures may have to affect multiple spheres of life, be intrusive into one area, and heavily restrictive of the right. Although the right in article 27 does not have a specific limitation clause, the Siracusa Principles on the limitation and derogation of provisions in the ICCPR may also play a role in enabling States to determine whether its actions fall within a permissible range of limitations. ${ }^{90}$ For example, the State bears the burden of justifying a limitation and limitations are: limited to those contained in the ICCPR itself; must not jeopardise the essence of the right; must be provided for by law; and subject to the possibility of challenge for remedy. ${ }^{91}$ Further, limitation clauses are to be interpreted "strictly and in favour of the rights at issue." 92

Section 5 of the Bill of Rights Act provides for justified limitations on the right to language. ${ }^{93}$ As for the ICCPR, the State bears the onus of proving that the limitation complies with section 5 of the Bill of Rights Act, ${ }^{94}$ and any limitation on the right to language has to be "prescribed by law". 95 The substantive test is whether the limitation is a reasonable limit and is demonstrably justifiable in a free and democratic society. In simplest terms, to meet this substantive test the limitation must have a significant and important objective, and the measures must be rationally

\footnotetext{
${ }^{88}$ See for example Rishworth, above n 61, 187-188. The "margin of appreciation" is where the judicial authority decides to defer to the State, as the matter relates to policy or distribution of limited resources (for example, decisions peculiarly within realm of government).

${ }^{89}$ See for example Mahuika v New Zealand, above n 36, para 9.4, Lansman v Finland (26 October 1994) UN Human Rights Committee CCPR/C/52/D/511/1992, para 9.4; and Lovelace v Canada, above n 68 , para 16.

${ }_{90}$ UN Sub-Commission on Prevention of Discrimination and Protection of Minorities "Siracusa Principles on the Limitation and Derogation of Provisions in the International Covenant on Civil and Political Rights" (1984) UN Doc E/CN.4/1984/4 Annex.

${ }_{91}$ See for example Siracusa Principles, above n 90, principles 1, 2, 5, 8, and 12.

${ }^{92}$ Siracusa Principles, above n 90, principle 3.

${ }^{93}$ New Zealand Bill of Rights Act 1990, s 5 states: "Subject to section 4 of this Bill of Rights, the rights and freedoms contained in this Bill of Rights may be subject only to such reasonable limits prescribed by law as can be demonstrably justified in a free and democratic society."

${ }^{4}$ See for example Ministry of Transport v Noort, above n 57, 283 Richardson J.

${ }^{95}$ See for example Ministry of Transport v Noort, above n 57, 283, Richardson J
} 
and proportionately connected to that objective. ${ }^{96}$ The Court of Appeal has acknowledged that assessment of this substantive test will necessarily involve value judgments of the specific limitation and its intrusion on the right. ${ }^{97}$

In respect of article II of the Treaty, Lord Woolf in the Privy Council decision of the Mâori Council broadcasting cases gave a useful overview of the obligation stating that it was not "absolute and unqualified" because that would be inconsistent with the Crown's other responsibilities as the government of New Zealand. Furthermore, Lord Woolf said that "[w]hile the obligation of the Crown is constant, the protective steps which it is reasonable to take change depending on the situation which exists at the time." 98 An assessment of what are reasonable steps includes consideration of the condition of the language and, in the case of the Mãori language, consideration of the available options against the Treaty principles. ${ }^{99}$

\section{Limits on the right to language must be "prescribed by law"}

In the New Zealand context, any limitation placed on the right to language contained the Bill of Rights Act must be assessed under section 5 of that Act and would need to be "prescribed by law". ${ }^{100}$ In the New Zealand context, Noort revealed that the limits could occur at the operational level as a necessary corollary of the statute. ${ }^{101}$

An interesting question arises where the State is found to be in breach of the right to language because they have failed to do something to guarantee the well-

\footnotetext{
${ }^{96}$ See for example Moonen v Film and Literature Board of Review [2000] 2 NZLR 9, 16-17; Moonen $v$ Film and Literature Board of Review [2002] 2 NZLR 754, 760; Ministry of Transport v Noort, above n 57; and Rishworth, above n 61, 172-194. This test was drawn from the Canadian Supreme Court's judgment in $R v$ Oakes [1986] 1 SCR 103. While these tests include a question about whether the limit reflects a minimal impairment on the right (ie: least intrusive), in practice these element seems to have been incorporated into the proportionality assessment.

97 See generally Moonen v Film and Literature Board of Review [2000], above n 96; and Ministry of Transport v Noort, above n 57.

${ }^{98}$ New Zealand Mãori Council v Attorney-General, above n 69, 513 (PC) Lord Woolf for the Judicial Committee.

${ }^{99}$ See generally New Zealand Māori Council v Attorney-General [1987] I NZLR 641; and Tainui Mãori Trust Board v Attorney-General (1989) 2 NZLR 413.

${ }^{100}$ See for example Ministry of Transport $v$ Noort, above n 57, 283 Richardson J. That simple, and seemingly obvious, phrase "prescribed by law" has lead to some interesting jurisprudence around the importance of the law being accessible and limitations being categorically framed. See for example Sunday Times $v$ United Kingdom (1979) 2 EHRR 245, 271.

${ }^{101}$ Ministry of Transport $v$ Noort, above n 57, 283 Richardson J.
} 
being of a minority language. According to the Rishworth text, what is clear is that the limit must have the force of the law and: ${ }^{102}$

[1]n principle, a strict interpretation of the requirement that limits be prescribed by law would preclude the courts from considering the reasonableness of limitation on rights flowing from the application of policies or procedures unless they were specifically authorised by law, but this requirement is sometimes glossed over.

Arguably, failure or omission by the State to prevent denial of minority languages would need to be prescribed by law in order for the State to rely on section 5 of the Bill of Rights Act. It is important to note that, given the ambit of section 3 of the Bill of Rights Act, the right to language applies not only to legislation but also to government policies.

Like section 5 of the Bill of Rights Act, the Siracusa Principles require all limitations on ICCPR rights to be "provided for by law". ${ }^{103}$ The interpretive principles for specific limitation clauses under the Siracusa Principles offer guidance about what "prescribed by law" means - to paraphrase - limitations must: ${ }^{104}$

- be provided for by national law of general application (which is consistent with the ICCPR and in force at time it is applied);

- not be arbitrary or unreasonable laws;

- clear and accessible to everyone;

- be accompanied by safeguards and effective remedies.

Meanwhile, the legal status of limitations on the Treaty right to language is less clear. The decisions of the Mäori Council broadcasting cases, in which the Crown was transferring and selling broadcasting assets, suggest that any limitations the Crown places on the right to language must be intra vires and consistent with the Treaty principles (that is, there is no requirement that the limitation must be prescribed by law). It, therefore, appears that the Bill of Rights Act and ICCPR may offer a higher standard of protection than the Treaty in this respect. However, the interpretation principles flowing from these sources may have judicial influence on

\footnotetext{
${ }^{102}$ Rishworth, above n 61, 175.

${ }^{103}$ Siracusa Principles, above n 90, principle 5.

${ }^{104}$ Siracusa Principles, above n 90, principles 15-18.
} 
the interpretation of limitations placed on the Treaty right given the practice of applying "ordinary legal principles" to interpreting the Treaty.

Chief Justice Elias recently reaffirmed that "basic rights cannot be overridden by general or ambiguous words in statute". ${ }^{105}$ The author has not identified any legislative provisions, or common law doctrines, that explicitly restrict the State from including consideration of the condition of minority languages as part of its functions including broadcasting, education, service delivery, or culture and heritage policy-making powers.

\section{Economic justifications}

The persistent argument, or justification, placed as a barrier to fulfilling the right to language is that economic constraints mean a State is unable to make the promotion of minority languages a priority. In general, economic justifications as a sole justification for a limit are rarely received with favour by courts unless it would be a 'prohibitive' cost. ${ }^{106}$

The Mãori Council broadcasting cases reveal a preoccupation with the financial constraints of the recession that the Crown was facing at the time of these cases. Justice McGechan observed that courts should take note of economic and political realities where funds are scare, considering them "as much a fact as weather". ${ }^{107}$ However, when the second round of cases saw the Crown before the Court of Appeal in 1996, they were not given the same latitude: ${ }^{108}$

\footnotetext{
With improvements in the economy, those assessments should be revisited. Treaty obligations are not static. I do not for a moment suggest the Crown is so flush with funds it can facilitate every pet project placed before it. It would soon be destitute. Nor do I presume to determine priorities in government spending. However, few would argue against the compelling necessity to protect a recognised taonga in the form of the Mãori language, under grave threat, and the simple fact is that funds are now more readily available. There is a way, if there is also a will.
}

\footnotetext{
${ }^{105}$ Ngati Apa ki te Waiponamu Trust v Attorney General [2000] 2 NZLR 659, paras 82-84 (CA) Elias CJ (dissenting).

${ }_{106}$ See for example Singh et al $v$ Minister of Employment and Immigration [1985] 1 SCR 177, 218220, Wilson J; and Peter Hogg Constitutional Law of Canada (Looseleaf edition, vol 2, 1997) para 35.9 .

${ }^{107}$ New Zealand Māori Council v Attorney-General, above n 55, 64 (HC) McGechan J. See also New Zealand Mãori Council v Attorney-General (29 July 1991) HC WN CP 942-88, 16-17 McGechan J; and New Zealand Māori Council v Attorney-General, above n 6, 580-581 (CA) Cooke P (dissenting).

${ }_{108}$ New Zealand Māori Council v Attorney-General (29 March 1996) HC WN CP 40-96, 5 McGechan J.
} 
The UN Committee has found that the "margin of appreciation" argument, which allows for limits on rights that can reasonable and necessary, is not relevant for limits on article 27. ${ }^{109}$ This argument often takes into account the financial constraints under which a State operates and how this influences policy and funding choices. The Court of Appeal in Moonen signalled that economic concerns may be one of several factors taken into account when considering arguments under section 5 of the Bill of Rights Act. ${ }^{110}$ The Court of Appeal has not had an opportunity to consider economic justification as a sole factor. The High Court did consider this matter in Lawson $v$ Housing New Zealand ${ }^{\prime \prime \prime}$ and found that while housing is essential, State subsidised rental housing is not a continuing State function. Justice Williams went on to state: ${ }^{112}$

All economic administrative and social consequences need to be weighed against the rights in the New Zealand Bill of Rights Act 1990 but the provision of subsidised rental housing is no longer regarded as being important in the public interest as was formerly the case.

This argument is more complex that just "economic justifications alone can be sufficient"; it involves a weighing up of the public interest. The greater the degree of language vulnerability (as was the situation for the Māori language in the Māori Council broadcasting cases) results in greater impetus for remedial action by the State. Where this need is tempered by economic constraints on the State, then a programme of action for revitalising a minority language is the best course. Such action is not, however, likely to be without criticism. For example, during the on the Māori Television Services Bill the New Zealand First Party expressed concern at the use of funding for Māori TV when there were other areas of considerable concern for Mãori (such as education, housing, health, and employment) which should take greater priority. ${ }^{113}$

\footnotetext{
${ }^{109}$ Lansman v Finland, above n 89, para 9.4; and Mahuika v New Zealand, above n 36, para 9.4. See generally Rishworth, above n 61,187-188.

${ }_{110}$ Moonen v Film and Literature Board of Review [2000], above n 96, 17 Tipping J for the Court.

11 Lawson v Housing New Zealand [1997] 2 NZLR 474 (CA).

112 Lawson v Housing New Zealand, above n 111, 495-496 Williams J for the Court.

${ }^{113}$ See for example (8 April 2003) 607 NZPD 4915.
} 


\section{In a Nutshell}

In New Zealand the right to language applies to all linguistic minorities and their ability to use their own language in community with other members of the group. The right to language has collective force where a minority language has become vulnerable due to action or inaction by the State. Doing nothing is not an option in situations where the vulnerability of the language is demonstrated. In respect of the right to language, therefore, it is fair to say that where the State is facing the need to revitalise a vulnerable language, then designing and implementing a programme of action (which accommodates the economic constraints facing a State) is necessary for the progressive revitalisation of one or more minority languages would ensure observance with the right to language.

\section{TE REO MĀORI \& LESSONS FOR REVITALISATION}

While New Zealand has three minority languages unique to its shores: Māori, Moriori, and New Zealand Sign Language; the focus of this paper is on the Mãori language and the lessons that can be learned from its revitalisation for the Moriori language. Further, both the Māori and Moriori languages are protected by all three sources of the right to language in New Zealand. This is in no way intended to diminish the importance of New Zealand Sign Language nor immigrant languages that, as New Zealand's cultural make-up continues to shift, become an increasing presence in our verbal landscape. The focus merely recognises that New Zealand has an arguably greater moral obligation to ensure a secure place for minority languages peculiar to its own territory. This part of the paper examines the application of the right to language to the Māori and Moriori languages.

\section{A Māori Language - Is New Zealand Now Meeting its Obligations?}

The Māori language has been described as "the foundation language of New Zealand, the ancestral language of the tangata whenua and one of the taonga guaranteed protection under the Treaty of Waitangi" in an article written by Kāretu and Waite. ${ }^{114}$ This article also describes te reo Mãori as being related to the Eastern Polynesian language grouping which includes languages such as Cook Island Māori, Tahitian, and Hawai'ian. In the Te Reo Report the Tribunal considered that the

\footnotetext{
114 T Kāretu and J Waite, "Te Reo Māori" in New Zealand Official Yearbook 1988-1989 (93 ed, Department of Statistics, Wellington, 1988) 217-227.
} 
question of which Māori dialect is, or should become, the "official" Māori language was not pivotal to the claim, and noted claimants suggestions for a governmentfunded body to regulate and promote the language on behalf of the whole community. ${ }^{115}$

A combined Statistics New Zealand and Te Puni Kökiri study of the 2001 census results showed an improvement in the numbers of Māori speakers and that 25 per cent of the Mãori population (or 130,500 Māori) identified as UN SubCommission on Prevention of Discrimination and Protection of Minorities Māori and 36 per cent of Māori households had at least 1 speaker of te reo Māori. ${ }^{116}$ It appears that while the proportion of Māori speakers in the Māori population was highest in the older age groups, most speakers of Mãori (46.62 per cent) were between the ages of 1-24 years. The older age groups are, however, more likely to be fluent in Māori and familiar with the nuances of the language.

Māori are a linguistic minority in New Zealand, and there is little doubt from the Te Reo Report and Māori Council broadcasting cases that the Māori language was in a vulnerable state in the 1980 s and 1990s without much hope for a bright future without State intervention. The vulnerable state of the Māori language meant that fewer Māori were conversing in the Māori language in community with each other because English dominated most common social forums such as: education, entertainment, broadcasting, media, public meetings, and home use. The findings by both the Tribunal and courts under article II of the Treaty that the Crown had failed to meetings its obligation to "guarantee" access to this taonga is clear and unambiguous.

At the time of these decisions, could this same finding have eventuated under the section 20 of the Bill of Rights Act and article 27 of the ICCPR, would the State have been found to have "denied" the right to language? In short, yes. These formulations of the right also capture State neglect and inaction that undermines the ability of a minority to use their own language in community with others. The evidence adduced to establish this fact in the courts under the Treaty would have had equal force in proceedings under the Bill of Rights Act and in a communication to the UN Committee.

\footnotetext{
115 Te Reo Report, above n 20, paras 8.2.10, see also paras 8.2.11-8.2.14.

116 See for example Te Puni Kōkiri Speakers of Māori within the Māori Population (Wellington, 2001); and Te Puni Kökiri Māori Language in the Community (Wellington, 2004).
} 
As for the proceedings in the Mãori Council broadcasting cases the State, during the late $1980 \mathrm{~s}$ and the 1990 s, would have had compelling arguments to support economic justifications for limiting the right (and the degree of any remedial action). However, such limitations would have to be "prescribed by law" to satisfy section 5 of the Bill of Rights Act and, as noted earlier, there are not any readily identifiable legislative provisions or common law doctrines that restrict the right to language. Nor are such justifications likely to succeed under the ICCPR. The right to language would not be assessed by reference to a "margin of appreciation" under the ICCPR, and neglect of a minority language is unlikely to be a measure that has limited impact on the way of life of persons belonging to a minority because language is the fundamental currency of community interactions.

The State has taken a "progressive realisation" approach in collaboration with (and prodded on by) Māori. The developments in Māori language education and broadcasting over the last two decades have resulted in a "renaissance" for the Māori language, and reduce the likelihood of the State failing to observe this right. However, should the State put is blinkers on when considering policy that impacts on language development and use, then Māori may again need to mount a claim under either the Treaty or the Bill of Rights Act (or ultimately, the ICCPR).

\section{B Moriori Language - Is New Zealand in Breach of its Obligations?}

Moriori are a linguistic minority. The Moriori people are the indigenous inhabitants of the Chatham Islands or Rekohu. In the 2001 Census, 663 of the 717 people normally resident on the Rekohu identified as belonging to one or more ethnic groups, and 390 identified as belonging to the "Maori" ethnic group. ${ }^{117}$ It is worth noting that although "Moriori" is not listed as a separate ethnic category, it is listed as an iwi, and in the 2001 Census approximately 585 people (up on 339 people in 1996, and 105 in 1991) identified as having Moriori ancestry, the majority of these people being under the age of 50 years. ${ }^{118}$ Not all of these people will live on

\footnotetext{
117 Statistics New Zealand "2001 Census of Population and Dwelling - Chatham Islands Community Profile" <http://www2.stats.govt.nz/domino/external/web/Comm Profiles.nsf/FindInfobyArea/597000-au> (last accessed 16 September 2006)

118 Statistics New Zealand "2001 Census of Population and Dwelling - Iwi, Volume 1" $<$ http://www.stats.govt.nz/NR/rdonlyres/AFFE02D4-BF71-4B51-A2B5-

7C58A7785FBA/0/IwiVoll.pdf >
} 
the Rekohu and the increase may be attributable to people taking a greater interest in their ancestry.

Michael King, a New Zealand historian, identifies that the Moriori people are of Māori and Polynesian origin, and travelled from New Zealand to Rekohu. On Rekohu the Moriori, while sharing common ancestry with the Māori, became a distinct culture - King notes some of these key differences and states: "These changes meant that when Moriori met Māori for the first time in the nineteenth century, each understood the other; but each also identified the other as a separate people." 119

As noted earlier, King describes the language as fundamentally the same as Māori but observes that the Moriori language had different idioms and pronunciation. As a result of the differences in pronunciation and the method of recording a language in writing, the written vocabulary appears to vary more and magnify the differences. ${ }^{120}$

The Rekohu Report sets out significant findings about the relationship between Maori, Moriori and the Treaty. In addition to the finding that the Treaty applied to native peoples (including Moriori), the Tribunal found, that the scientific evidence was compelling and that Moriori people are the same as Mãori and, as such, the Tribunal found that the Treaty protected Moriori. ${ }^{121}$ The Tribunal also considered, given the different societal practices that had emerged, that the Moriori people were entitled to separate recognition as a distinct section of the Māori people. As a result of inaction by the State the ability for Moriori to use their language in community with their group is seriously threatened. The Tribunal, while making little reference to the Moriori language, recognised that: ${ }^{122}$

The long-term consequence [of the Crown failing to intervene] is that Moriori as a people, and their culture and integrity, are now seriously at risk, to the detriment of both the country and the descendents of the few survivors.

\footnotetext{
119 A Land Apart, above n 76, 11. See also Michael King Moriori: A People Rediscovered (Viking: Penguin Books (NZ) Ltd, Auckland, 1989).

120 A Land Apart, above n 76, 11; and A People Rediscovered, above n 119, 33 and $195-203$

(Appendix containing a vocabulary list).

${ }_{122}$ Rekohu Report, above n 56, paras 2.1-2.10 and 14.1

${ }^{122}$ Rekohu Report, above n 56, para 14.1 .
} 
The Tribunal recommended the Crown compensation be directed to Moriori "cultural re-establishment and the social, economic, and cultural development of the people" (paragraph 14.2 of Rekohu Report). The Moriori language is in serious jeopardy; it has a very small group of potential native speakers, and those familiar with the language are limited and aging. Given the current state of the language, and the findings of the Tribunal in the Rekohu Report it is highly likely that Crown would be found in breach of its obligations under all three of the sources of the right to language.

As for Māori and other minority languages, there is no readily identifiable legislative or common law provision for limiting the right to language. Therefore, neglect by the Crown would not be justifiable under the reasonableness test of the Treaty (given the decision in the Mãori Council broadcasting cases), section 5 test under the Bill of Rights Act, nor ICCPR standard. Urgent attention and commitment by both the State and the Moriori people is required to revitalise the Moriori language.

\section{TWO MODES OF REVITALISING A MINORITY LANGUAGE}

Where a language has become vulnerable and its survival is tenuous a trio of influences has been advocated to revitalise a language: education, home use, and broadcasting. ${ }^{123}$ Official recognition is also considered beneficial in terms of revitalising a language, this recognition may be symbolic initially until the language is strong enough to be incorporated more fully into institutional structures and society. This part of the paper looks at what lessons can be learned from the Mãori experience of revitalising the language specifically vis-a-vis official recognition and television broadcasting.

\section{A Official Recognition}

While official recognition of minority languages may form part of a State's observance of the right to language, it is distinct from the right to language itself. This is because while the right to language focuses on the ability for members of a linguistic minority to communicate with each other, in contrast, official recognition of a minority language largely focuses on the relationship between the State and

123 See for example New Zealand Māori Council v Attorney-General, above n 55, 60-62 (HC) McGechan J. 
minority (that is providing individuals with the ability to use their language in dealings with the State). The right to language and official recognition of a minority language are not mutually exclusive concepts. In many situations official recognition of a minority language, accompanied by language planning, contributes to the revitalisation of a minority language because it raises the status or regard for that language in the eyes of the linguistic community, the State and society generally.

International language planning research, as discussed in the Te Taura Whiri i te Reo Māori (Māori Language Commission) resource for Māori language planning, has identified five primary areas that account for language health: ${ }^{124}$

(a) language usage (including frequency, domains, and substance);

(b) language status (the value placed on language by its linguistic community, general society, and the State);

(c) language acquisition (the number of speakers, modes of acquisition, and proficiency);

(d) language corpus (the ability for vocabulary to reflect the changing social and technological environment);

(e) critical awareness of language (knowledge of well-being of language, and how to access learning and speaking opportunities).

For official recognition to accomplish revitalisation of a language and to promote the right to language there needs to be a "good showing" across these five primary areas of language health.

\section{Different methods of official recognition}

Official recognition can take several different forms: statutory declaration, constitutional declaration, and statutory declaration accompanied by State administration requirements. While the Welsh Language Act 1967 provided for the use of Welsh language in public administration and court proceedings, its successor Welsh Language Act 1993 went on to promote more substantial advancement of the

\footnotetext{
124 Māori Language Commission "Māori Language Planning - What is Language Planning?" $<$ www.tetaurawhiri.govt.nz/english/services_e/intro_what.shtml $>$ (last accessed 30 July 2006)
} 
language - the Welsh Language Board describes the 1993 Act's three main accomplishments as: ${ }^{125}$

- [placing] a duty on the public sector to treat Welsh and English on an equal basis, when providing services to the public in Wales

- [giving] Welsh speakers an absolute right to speak Welsh in court

- [establishing] the Welsh Language Board to oversee the delivery of these promises and to promote and facilitate the use of the Welsh language.

Further, the Board notes that it's approach to "its statutory duty is based firmly on what is appropriate under the circumstances and reasonably practicable."126

In contrast, Article 8 of the Irish Constitution created a hierarchy of official languages: Irish being the first official language (article 8.1) and English being the second official language (article 8.2 ). Article 8.3 provides that exclusive use of one of the two official languages can be provided for by law. It is important to note that these changes occurred as part of constitutional change, clearly marking the direction Ireland would take as a bilingual nation.

In Canada, the two colonial languages, French and English, receive equal official recognition under the Official Languages Act 1969. This Act saw French integrated into all federal institutions and public administration. Although the overarching focus of language recognition is on English and French, ${ }^{127}$ some indigenous languages such as Inuktitut, Dene Suline, Cree, Dogrib, and Gwich'in have also gained limited official recognition. For example, Inuktitut became an official language in Nunavut when the new territory was created in 1999 (44 per cent of the population spoke Inuktitut as their mother tongue in 2001). ${ }^{128}$

None of these jurisdictions have a general domestic right to language equivalent to section 20 of the Bill of Rights Act or the Treaty; they do, however, have access to the right to language under article 27 of the ICCPR. It is curious that while two of these jurisdictions have also recognised English, the dominant

\footnotetext{
125 Welsh Language Board <www.bwrdd-yr-iaith.org.uk/cynnwys.php?pID $=104 \&$ langID $=2>$ (last accessed 8 August 2006).

${ }_{127}^{126}$ Welsh Language Board, above n 125.

127 See for example Canadian Office of Commissioner of Official Languages <http://www.ocolclo.gc.ca/archives/ar ra/2005 06/2005 06_e.pdf> (last accessed 20 September 2006).

${ }^{128}$ Statistics Canada "Multicultural People" <http://142.206.72.67/02/02a/02a_007_e.htm \#t02> (last accessed 20 September 2006).
} 
language, as an official language - New Zealand has only officially recognised two minority languages: Māori and New Zealand Sign Language. ${ }^{129}$

\section{Mãori Language Act 1987}

The Māori Language Act 1987 (the Act) provides legal recognition of Māori as an official language; enables Māori to be spoken in legal proceedings; and establishes the Mãori Language Commission. A predecessor, section 77A of the Māori Affairs Act 1953 (as amended by the Māori Affairs Amendment Act 1974) provided for "official recognition" of the Mäori language but nothing of substance flowed from it.

The Māori Language Bill was introduced to the House on 29 April 1986, days before the reiease of the Te Reo Report, by the then Minister of Māori Affairs Hon K T Wetere who emphasised in his introduction that: ${ }^{130}$

\footnotetext{
In the opinion of the Mãori people, and of the Government, the language was one of the matters dealt with in the Treaty of Waitangi. It is a taonga - a treasure passes down from ancestors. It is the objective of the Government that the Māori language should be retained with all its vibrancy. The Bill also expressly states that the Mãori language was confirmed and guaranteed in the Treaty of Waitangi.
}

The implication of this statement is that the Crown saw official recognition as an important step in observing the right to language and giving the right legal effect. Both the Crown and Tribunal clearly saw official recognition of the Māori language as a way of implementing, or observing, the right protected in the Treaty. The Act was not intended to give rise to a new right to language, the rights of any person: "... are not extended or restricted in relation to the use of the Māori language, apart from what is contained in the Bill. Nor does it restrict the use by any person of any other language." 131

The Act does not define what it "means" to make Māori an "official language" of New Zealand. Instead, section 7(a) of the Act confers on the Māori Language Commission the function to:

\footnotetext{
129 New Zealand Sign Language Act 2006, s 3. See also (22 June) 618 NZPD 13774-13785.

${ }^{130}$ (29 April 1986) 470 NZPD1450-1452.

${ }^{131}$ (29 April 1986) 470 NZPD 1452.
} 
[I]nitiate, develop, co-ordinate, review, advise upon, and assist in the implementation of policies, procedures, measures, and practices designed to give effect to the declaration in section 3 of this Act of the Mãori language as an official language of New Zealand.

Because of this, the Act has been criticised as being largely symbolic and not going far enough to give the Mãori language the "true" official status sought by the recommendations of Te Reo Report. For example, the Act does not enable "any person who wishes to do so to use the Māori language in ... any dealings with Government Departments, local authorities and other public bodies". ${ }^{132}$ Te Ururoa Flavell MP recently questioned what the point was of affording the Mãori language official recognition if the simple things, such as having signage in te reo Māori on a bus for a kura kaupapa Māori school, were stymied. ${ }^{133}$ This press release echoes some of the criticism levelled at the Bill when it was before the House. Members of the Opposition did not formally oppose the Bill but seemingly sought, during debates, to clarify what it meant to make the language official; did it, for example, give the Māori language equal status with English? ${ }^{134}$ This question, to date, remains unanswered in legal terms - this approach is in stark contrast with the Irish Constitution that clearly establishes a hierarchy for the two official languages.

\section{What could official recognition do for the Moriori language?}

Unlike Māori, remedial action for the Moriori language may need to take a different course because official recognition is less of a priority than language education and acquisition at this stage; once such education has taken hold then official recognition may be a vital next step in securing its place in the fabric of New Zealand.

Official recognition of Moriori may prove to be a blunt instrument if an entity is not given responsibility for executing the work necessary to give effect to that recognition. The Mãori Language Commission has a single focus that is unlikely to get crowded out by other policy imperatives and, as such, has been able to develop resources not only to promote Māori language acquisition and retention,

\footnotetext{
${ }^{132}$ Te Reo Report, above n 20, para 10.

${ }^{133}$ Te Ururoa Flavell MP "When an official language, isn't official" (23 June 2006) Press Release.

${ }^{134}$ See for example (29 April 1986) 470 NZPD 1450-1468.
} 
but also to develop a language planning framework. However, if New Zealand is serious about its commitment to strengthening its national identity, then governmental oversight is necessary to ensure minority languages and cultures have a "secure place" in State education, broadcasting, public sector employment, and service delivery policies.

Securing funding and access to resources is an overriding concern. One possible solution is to design and implement a Moriori language strategy. Funding to deliver the strategy could be a joint responsibility of the Moriori people (using some of any compensation from the Crown resulting from the Rekohu Report) and the State (additional funding and, for example, broadening the mandate of the Māori Language Commission, that has expertise in language revitalisation, to include work for the Moriori language).

\section{B Television Broadcasting}

Broadcasting, both radio and television, has been considered an important tool to revitalise a minority language, ${ }^{135}$ relative to the degree that education or home use are insufficient in promoting the language: ${ }^{136}$

Radio and television have an unparalleled influence on how people view themselves, their country and the world.

With the ability to reflect and explore every aspect of New Zealand life, what we see and hear on television and radio plays an important part in shaping our national identity, both for us as New Zealanders and in the way the rest of the world sees us.

Therefore, television broadcasting, despite often being maligned for "dumbing down" the populace, provides a vital medium for promoting language because it

135 New Zealand Māori Council v Attorney-General, above n 55, 62 (HC) McGechan J; and New Zealand Mäori Council v Attorney-General, above n 6, 587-588 (CA) Hardie Boys J; and Thornberry, above n 3, 200.

${ }^{136}$ MCH Anmual Report, above n 13, 5 . 
exposes the language to a mass audience, is a medium popular with a younger generation, and gives language "credibility": ${ }^{137}$

... [B]roadcasting under conditions of modern life certainly has a part to play. It is an important part. with two aspects. First, the more a language is used the better its chances. ... Second, I accept that there is a subtler dimension. The media, particularly the audio-visual medium of television, is a powerful instrument in shaping mass perceptions.

The Mâori Council broadcasting cases canvas the different options for television broadcasting from prime time mainstreaming of Mãori language programmes to establishing a specialised channel. ${ }^{138}$ The judgments acknowledge that it is largely the role of the Crown to determine the appropriate course of action, but consider that the court's role is to ensure that whatever action is taken fulfils the Crown's obligations, and does not contravene the Treaty principles. ${ }^{139}$ The nature of State intervention of television broadcasting to promote a minority language is likely to be heavily influenced by the vulnerability of the language, and goals underpinning the future relationship between that minority and the State.

\section{Māori language television broadcasting}

New Zealand has had a smattering of Māori language programmes over the years including:

- Te Karere, a news programme;

- Pūkana, a children's educative programme;

- trial by Aotearoa Television Network of a free-to-air television service in the Auckland area.

Te Māngai Pāho, the Māori Broadcasting Funding Agency, was established in 1993 to promote the Māori language through both radio and television broadcasting. The major development, however, occurred for Mãori language television broadcasting with the establishment of the Mãori Television Service (Mãori TV).

\footnotetext{
${ }^{137}$ New Zealand Mãori Council v Attorney-General, above n 55, 61 (HC) McGechan J. See also New Zealand Māori Council v Attorney-General above n 6, 601 (CA) McKay J; and New Zealand Māori Council v Attorney-General above n 69, 518 (PC) Lord Woolf for the Judicial Committee.

${ }_{138}$ See for example New Zealand Mâori Council v Attorney-General, above n 55, $84-86$ (HC) McGechan J.

${ }^{139}$ New Zealand Mãori Council v Attorney-General, above n 55, 87 (HC) McGechan J.
} 
Māori TV was established as a statutory corporation in May 2003 by the Māori Television Service (Te Aratuku Whakaata Irirangi Māori) Act 2003 (the Māori Television Act). The preamble to the Māori Television Act makes explicit reference to both the Te Reo Report and the Privy Council decision of the Mãori Council broadcasting cases, and acknowledges the importance of providing both the Māori language and culture with a secure place.

The structures put in place around Māori TV reflect the joint responsibilities of the minority and Crown, while balancing constitutional and legal practices around autonomous commercial entities. ${ }^{140}$ The responsibilities placed on the Māori TV and its Board include requirements to develop a plan for promoting the Māori language and culture, and measuring its success. ${ }^{141}$

\section{Broadcasting of the Moriori language}

The Ministry of Culture and Heritage notes that recent statistics reveal that "77 [per cent] of New Zealanders surveyed feel that seeing ourselves on television and hearing stories helps to develop our cultural identity."142 Despite this statement there is not specific reference to language as the base unit for culture, nor broadcasting in languages other than English in their Annual Report 2005, nor a programme of action for public broadcasting. ${ }^{143}$ Reading between the lines, the goal to develop local and regional broadcasting may enable linguistic minority communities inhabiting a specific radius in New Zealand to be able to gain support for broadcasting in their own language. ${ }^{144}$

It is within regional development that the benefits may come for the Moriori language. Television broadcasting can be received in the Chatham Islands to varying degrees - in addition to being able to receive SKY digital satellite services, the Chatham Islands have an analogue terrestrial transmission system on which TVNZ and other programmes are selected locally and (re)broadcast (this enables

\footnotetext{
${ }^{140}$ See for example Māori Television Act, ss 7, 12-18. The Mãori Television Act establishes Māori TV as a body corporate, and sets up a Māori Electoral College to safeguard the interests of Mãori (including appointing four of the seven directors of the Board. See also Mãori Television Service Statement of Intent 2005-2006 (Auckland, 2005) 4-6.

${ }_{141}$ See for example Mãori Television Act, ss 25-44; and Statement of Intent 2005-2006, above n 140, 8-14.

${ }^{142}$ MCH Annual Report, above n 13, 2.

143 Ministry of Culture and Heritage Building a Stronger and Sustainable Public Broadcasting Environment for New Zealand - A Programme of Action <www.mch.govt.nz/publications/publicbroadcasting/public-bdcast.html> (last accessed 30 July 2006).

${ }^{144}$ A Programme of Action, above $\mathrm{n} 143$.
} 
reception by conventional television receivers). If funding was available to enable the production of language programmes to teach the Moriori language (possibly using the instructive models developed by Mãori TV), then such programmes could be broadcast locally in the Chatham Islands to promote language acquisition. Relaying these broadcasts using the internet is an option for conveying the language to the broader Moriori community not resident in the Chatham Islands.

\section{GUIDING PRINCIPLES FOR STATE OBSERVATION}

In recognition of the challenges a State faces in meeting its many human rights obligations, the following have been identified as guiding principles for observing the right to language. It is worth noting that these principles may well prove to have a broad application across many minority languages, and other rights with relational aspects requiring progressive realisation to achieve a positive outcome.

\section{A Introduction}

\section{$1 \quad$ Politics and law making}

The manner in which a State observes the right to language is heavily influenced by the political philosophies of sway within a nation. Adeno Addis, a Professor of Law at Tulane University, provides a useful survey and critique of many of these political approaches in respect of the right to language. ${ }^{145}$ The range of approaches varies from denial of minority cultures within a State's territory, to a market approach (society placed as determiner of which languages survive and in what form), to recognising only national languages (based on the theoretical proposition that immigrant languages have been abandoned "by choice"), to a critical pluralist approach which sees the integration of minority languages into the institutions and frameworks of the State. Addis advocates the critical pluralist approach as being most likely to achieve the goals of peace and stability within a nation, concluding that: ${ }^{146}$

The question of how to develop the capacity to live with difference, where difference is going to be the defining feature of almost all political communities, is

\footnotetext{
145 Addis, above n 12.

${ }^{146}$ Addis, above n 12, 789.
} 
the major question of the twenty-first century. What we cannot afford to do is either continue to play "the politics of indifference" or to resort to the quick fix of politics of divorce. Each has been tried and has given us not peace and stability but conflicts and discord. The monolingual nation has rarely existed in the real world; it should cease to control our imagination and deliberation about the appropriate institutions for a multicultural and multilingual world.

The Parliamentary debates on the Māori Television Services Bill ${ }^{147}$ offer a wealth of critiques on the role of the State in legislating around minority languages; these debates reflect several of the different political approaches to the right to language examined by Addis. ${ }^{148}$ The questions raised by the critiques centre on issues such as perceived "special treatment" for Māori (for example, is this a paternalistic or segratatory response?), accountability mechanisms, how to measure "success", the ability for television to "educate", the risks of political interference, and securing consistent levels of funding. As noted earlier, the most pressing criticism levelled was that the financial resources for Māori TV could be better used serving the greater social and economic priorities for Mãori. Nevertheless, the New Zealand Legislature has, in two instances, passed legislation promoting the use of a minority language in specific circumstances and made commitments to pursuing greater integration of those languages into the delivery of public services, including broadcasting.

With this in mind, the challenge is to identify principles that may assist in delineating the ambit of State observance of the right to language in the New Zealand context. ${ }^{149}$

\section{Principles of the Treaty of Waitangi as foundation}

In the New Zealand, the "Treaty principles"150 as applied in the Mãori Council broadcasting cases provide a sound starting point for establishing principles for observing the right to language. The Treaty is focused on maintaining a relationship between the State and Māori, a linguistic minority, and the constitutional

147 (5 December 2001) 597 NZPD 13518-13534; (8 April 2003) 607 NZPD 4908-4924; (9 April 2003) 607 NZPD 4986 - 5030; (10 April 2003) 607 NZPD 5065-5082; (29 April 2003) 608 NZPD 5106-5I13; (1 May 2003) 608 NZPD 5279-5291; and (6 May 2003) 608 NZPD 5350-5358.

${ }^{148}$ The Te Reo Report sets out responses to common objections to the recognition of te reo Māori as an official language of New Zealand for closer examination in the research paper.

149 See for example Thornberry, above n 3, ch18; and Mahuika v New Zealand, above n 36, para 9.4

150 The term "Treaty principles" has become shorthand for the substance of the Court of Appeal decision in New Zealand Mãori Council v Attorney-General [1987] 1 NZLR 641. 
place of the Treaty principles has been explicitly recognised by the State. ${ }^{151}$ If New Zealand wishes to pursue an inclusive society, then a positive relationship between the State and minorities is an integral part of the process. The Treaty principles were arrived at in a manner consistent with the "ordinary legal principles applicable to the interpretation of treaties." 152 Finally, the Mãori Council broadcasting cases are the leading New Zealand cases on the right to language; this right has not been contested under the Bill of Rights Act nor via a New Zealand Communication under ICCPR.

The Treaty principles have been the subject of much controversy and debate both in public and political arenas. The main complaint seems to be that the principles are vague and ambiguous, and the latest political attack on the Treaty principles has come in the form of a Member's Bill titled "Principles of the Treaty of Waitangi Deletion Bill" (Principles Deletion Bill) in the name of Opposition MP Doug Woolerton of the New Zealand First Party. ${ }^{153}$ The Principles Deletion Bill proposes to remove several legislative references to the principles of the Treaty, and the Explanatory Note usefully summarises the main arguments advanced against the Treaty principles over the years:

- The principles were inserted into legislation "not at the request of Māori, but by paternalistic and interfering Ministers".

- The principles remain "largely undefined and ambiguous" because Parliament failed to define the principles and left them open for the Courts to interpret, and Judges "have taken an increasingly activist, liberal, and broad licence in providing a form of definition".

- The meaning and relevance of the principles are the subject of constant litigation and "there has been no tangible benefit for Māori as a consequence of their existence".

- The principles "have become a diversion away from the true pathway to success for both Māori and non-Māori” and have reinforced a victim mentality for Māori.

\footnotetext{
151 Approximately 32 references in legislation.

152 Te Reo Report, above n 20, para 4.2.6. See generally Waitangi Tribunal The Manukau Claim: $W A I 8$ (Department of Justice, Wellington, 1985) ch 8.

${ }^{153}$ The Principles Deletion Bill received its first reading on 26 July 2006 and was referred to select committee for consideration.
} 
During the debates in the House on the Principles Deletion Bill and in oral questions that week about the Treaty principles the Government defended the Treaty principles, emphasising that they were not undefined and ambiguous and that the courts have consistently applied those principles. ${ }^{154}$ He Tirohanga o Kawa kit e Tiriti o Waitangi ${ }^{155}$ a text produced by Te Puni Kōkiri, for example, provides a guide to the application of the Treaty principles for government action and draws extensively on the expressions of the Treaty principles by the courts and the Tribunal. Principles, like human rights, are often the subject of a degree of suspicion because they do not nail down the exact rules to be followed in a particular situation. 156 The Treaty principles, like other legislative principles, require this high level approach because of the wide-ranging interests they interact with.

Regardless of these arguments the Tribunal, courts, and State (through the enactment of the Māori Television Act) have clearly defined how the Treaty principles are to apply to the right to language (specifically the Mãori language) and the Crown has acted on these judgments.

\section{B State to be Informed about Well-being of Minority Languages}

To observe the right to language, a State must be informed about the wellbeing of minority languages: ${ }^{157}$

Clearly the Crown must inform itself. A decision is not made fairly, or reasonably (otherwise than by accident) if it is made on a basis of avoidable ignorance. The process of self-information may require consultation ....

The State needs to be informed about (i) the current usage of the minority language, and (ii) whether the language is in a vulnerable state. This includes not only conducting research into the usage of the minority language but also enquiry into the potential outcome and impact of proposed policies on the ability for individuals to exercise their right to language. If a State is informed about these

154 (26 July 2006) 632 NZPD 4418. See also (13 February 2003) 606 NZPD 3421-3423.

155 Te Puni Kōkiri He Tirohanga o Kawa ki te Tiriti o Waitangi (Te Puni Kōkiri, Wellington, 2001).

${ }^{156}$ For example, both the Privacy Act 1993 and the Official Information Act 1982 contain principles that require interpretation and application on a case by case basis, and have also be subject to criticism of lacking clarity and certainty.

${ }_{157}$ New Zealand Māori Council v Attorney-General, above n 55, 19 (HC) McGechan J. See also: New Zealand Mäori Council v Attorney-General, above n 69, 517-518 (PC) Lord Woolf for the Judicial Committee. 
matters then it can assess what impact policies may have on that language and limit the risk of its actions, or inaction, eroding a minority language further and result in the denial of the right to language. Not only does this principle reek of commonsense, it has parallels with the observance of human rights under the Bill of Rights Act and the ICCPR.

The Bill of Rights Act applies to acts done by "the legislative, executive, or judicial branches of the government of New Zealand" (section 3(a) of the Bill of Rights Act) and the Attorney-General, by virtue of section 7 of that Act, is required to bring provisions of any bills that are inconsistent with the rights and freedoms contained in the Bill of Rights Act to the attention of the House upon introduction of the bill. To promote consistency with the Bill of Rights Act the Cabinet Office Manual requires government departments to discuss the human rights implications of their proposals in papers submitted to Cabinet, ${ }^{158}$ and the Ministry of Justice has published guidelines for assisting government departments in examining the Bill of Rights Act and human rights implications of their proposals. ${ }^{159}$ In essence, being informed about the implications of a policy is part of good policy making. Therefore, where policies such as education curriculum, publishing, broadcasting, civil participation, and funding of public services touch on language use detailed thought needs to be applied to the impact those policies may have on a minority group being able to use its language. This becomes critical where a minority language is in a vulnerable condition and requires revitalisation.

New Zealand is required under article 40 of the ICCPR to provide periodic reports to the UN Committee about its compliance with the rights contained in the ICCPR. By necessary implication, this means that New Zealand would need to be informed about the well-being of minority languages and cultures within New Zealand for the purposes of reporting on article 27 of the ICCPR. New Zealand's Third and Fourth Periodic reports do not offer insight into State interpretation of the

158 Cabinet Office Cabinet Manual 2001 (Wellington, 2001) paras 5.21, 5.35 and 5.39. See also Cabinet Office Step by Step Guide: Cabinet and Cabinet Committee Processes 2001 (Wellington, 2001 as updated in September 2005) paras 3.53-3.60, 7.6-7.12.

${ }^{159}$ Ministry of Justice The Guidelines on the New Zealand Bill of Rights Act 1990: A Guide to The Rights and Freedoms in the Bill of Rights Act for the Public Sector (Ministry of Justice, Wellington, 2004); and Ministry of Justice The Non-Discrimination Standards for Government and the Public Sector Guidelines on how to apply the standards and who is covered (Ministry of Justice, Wellington, 2002). 
right. ${ }^{160}$ The "Third Periodic Report" discusses a range of things including: the position of Māori; Māori language development; and broadcasting to promote the Mãori language and culture. The "Fourth Periodic Report" takes a different approach and seems to focus its discussion on how Mãori and other minority groups are faring in New Zealand society, and discusses policies that are targeting disparities between minorities and the majority. It does, however, comment on broadcasting and Māori language measures including on funding and "enabling" broadcasting; research to assist with planning; and the Mãori Language Strategy. ${ }^{161}$

Being informed about the well-being of a minority language to ensure robust decision-making is likely to require consultation with that minority, and is discussed below as part of the partnership principle. It is important to note that consultation should not been seen as the exclusive method of collecting information about a language, nor should the "duty to consult" eclipse (or act as a substitute for) the need for empirical research into a language's health. All of the five primary language health areas ${ }^{162}$ require demonstrable evidence to measure the progress of language revitalisation; such evidence cannot always be identified through population consultation with the minority groups. The State is in a unique position to collect such data and information (for example, as part of the census); and it is important that such data be available not only to the State but also academics and the linguistic minority groups themselves so that they are in a position to independently assess their language health.

For example, both Statistics New Zealand and Te Puni Kōkiri are now working together to collect data and report on the usage of the Māori language. ${ }^{163}$ Statistics New Zealand also collects and analyses data on other cultures in New Zealand. ${ }^{164}$

\footnotetext{
${ }^{160}$ United Nations Human Rights Committee "Third Periodic Reports of States parties due 1990: New Zealand" (30 May 1994) CCPR/C/64/Add.10, paras 132-144; and United Nations Human Rights Committee "Fourth Periodic Report of States parties due 1994: New Zealand" (7 March 2001) CCPR/C/NZL/2001/4, paras 245-193.

${ }_{161}$ Fourth Periodic Report, above n 160, paras 270-276

${ }^{162}$ See Part IV A Official Recognition.

${ }^{163}$ See generally above $\mathrm{n} 116$.

${ }^{164}$ See Part I B Cultural and Linguistic Diversity in New Zealand.
} 


\title{
C Partnership between the State and the Minority
}

The Mãori Council broadcasting cases, and the wealth of other judicial decisions and Tribunal findings about the Treaty, characterise the relationship between the Crown and Māori as one of partnership: ${ }^{165}$

\begin{abstract}
It was held unanimously by a Court of five judges, each delivering a separate judgment, that the Treaty created an enduring relationship of a fiduciary nature akin to a partnership, each party accepting a positive duty to act in good faith, fairly, reasonably, and honourably towards each other. The words of the reasons for the judgments of the five judges differed only slightly the foregoing is a summary of their collective tenor.
\end{abstract}

The construction of this principle is dependant on the Treaty because the Treaty stipulates the parties to the agreement and formalises the "fiduciary relationship" suggesting that where the minority and the State are not both parties to such an agreement, then this obligation is not owed. However, the ICCPR, which has domestic force by virtue of the Bill of Rights Act, is a treaty for which linguistic minorities, like individuals, are beneficiaries. Further, the UN Committee has formally recognised that: ${ }^{166}$

$\ldots$ [I]n the case of indigenous peoples, the enjoyment of the right to one's own culture may require positive legal measures of protection by a State party and measures to ensure the effective participation of members of minority communities in decisions which affect them.

The preservation of a culture and language is not the sole burden of the State - it is a joint responsibility between the State and the minority. ${ }^{167}$ This principle also speaks of commonsense, as a linguistic minority must seek to promote its own language development to ensure its survival - language acquisition and health is not a passive exercise. In essence, the State has the lion's share of responsibility for

\footnotetext{
165 Te Runanga o Wharekauri Rekohu v Attorney-General [1993] 2 NZLR 301, 304-305 Cooke P discussing the decision in the New Zealand Mãori Council v Attorney-General [1987] 1 NZLR 641.

${ }^{166}$ Mahuika $v$ New Zealand, above n 36, para 9.5; and General Comment No 23, above n 2, para 3.2.

167 See for example New Zealand Mäori Council v Attorney-General, above n 107, 16, McGechan J; New Zealand Māori Council v Attorney-General, above n 7, 35 (CA) Thomas J dissenting; New Zealand Mãori Council v Attorney-General, above n 69, 518-519 (PC) Lord Woolf for the Judicial Committee; and Addis, above n 12, 767-769.
} 
ensuring its policies, acts, and omissions do not impinge on the ability for a minority to enjoy their language in community with others. ${ }^{168}$ In addition, a State is to take positive steps to ensure the survival of the minority language where it is vulnerable. ${ }^{169}$

The minority is also responsible for promoting the use of its language in the community (such as through home use), and working with the State to advocate policies and measures to promote their language. ${ }^{170}$ Furthermore, to avoid criticism of paternalism a State can only act legitimately where the desire for a language to survive and prosper comes from the minority itself. Having noted this, a State may find itself in a difficult position when a language becomes vulnerable and its survival is met with apathy due to its progressive loss and lack of fluent speakers in the younger generations. In these situations, a State may be required to promote discussion around the language health to ascertain whether action, by both parties, will be beneficial and promote great collaborative contribution not only to language revitalisation but also to the State as a whole.

If it appears that a proposed course of action may impact on a minority's ability to practice its language then the State should seek to consult and negotiate an agreed policy or solution with the minorities concerned. ${ }^{171}$ The Crown in New Zealand accepted this principle, and the development of the Mãori Television Service Bill saw extensive consultation between Māori and the Crown. The Explanatory Note and Parliamentary debates on the Māori Television Service Bill reference the complementary roles and responsibilities of the Crown and Māori in promoting te reo Māori - for example, the Explanatory Note states:

Key principles for the provision of the Service, identified by Mãori stakeholders and the Government, are:

\footnotetext{
${ }^{168}$ See for example New Zealand Māori Council v Attorney-General, above n 107, 15 McGechan J; New Zealand Mäori Council v Attorney-General, above n 6, 588-589 (CA) Hardie-Boys J.

169 New Zealand Mäori Council v Attorney-General, above n 69, 517 (PC) Lord Woolf for the Judicial Committee; Thornberry, above n 3, 184-186; and General Comment No 23, above n 2, para 9.

${ }^{170}$ See for example New Zealand Māori Council v Attorney-General, above n 69, 518-519 (PC) Lord Woolf; for the Court; and New Zealand Mãori Council v Attorney-General, above n 7, 25 (CA) Thomas J dissenting.

${ }^{171}$ New Zealand Mäori Council v Attorney-General, above n 55, 20 (HC) McGechan J.
} 
(a) the Crown and Mãori together have a Treaty of Waitangi obligation in preserving, protecting, and promoting te reo Mãori, which is evidenced by the involvement of Māori and the government in the accountability and governance arrangements for the Service....

Addis advocates the integration of linguistic minorities into the fabric and institutions of the State. ${ }^{172}$ While this approach goes further than the right to language (which focuses on the ability for linguistic minorities to use their language within their own community) participation in the decision-making process and a positive relationship with the State reduces the chances for linguistic minorities to be marginalised by general policies and laws of the State.

\section{Active and Protective Role of the State}

"Last but far from least, in view of the Treaty guarantee to protect the language, the Crown must endeavour to avoid unnecessary damage to the language." ${ }^{173}$ The State's role is both a protective and active one. While this principle has been explicitly expressed in terms of the Treaty protection of the Māori language, ${ }^{174}$ it has its pedigree in the common democratic ideal that the State is responsible for ensuring the "weaker" members of society are not trampled upon nor marginalised. ${ }^{175}$ In essence, this principle would see the State taking positive steps to ensure the survival of minority languages where they are vulnerable. ${ }^{176}$ This view is consistent with the UN Committee's approach to the right: "Positive measures of protection are, therefore, required not only against the acts of the State party itself, whether through its legislative, judicial or administrative authorities, but also against the acts of other persons with the State party."177

Is this principle sustainable for the right to language in light of the decision in Mendelssohn? Mendelssohn makes some general comments about the right and restricts the role of the State to a primarily negative construction: the only

\footnotetext{
${ }^{172}$ Addis, above n 12, 773-789.

${ }^{173}$ New Zealand Mãori Council v Attorney-General, above n 55, 21 (HC) McGechan J.

${ }^{174}$ See for example New Zealand Mäori Council v Attorney-General, above n 55, 20 (HC) McGechan J.

i7s See generally Isaiah Berlin Two Concepts of Liberty: An Inaugural Lecture delivered before the University of Oxford on 31 October 1958 (Clarendon Press, Oxford, 1959).

${ }^{176}$ See for example: New Zealand Mãori Council v Attorney-General, above n 69, 517 (PC) Lord Woolf for the Judicial Committee; Thornberry, above n 3, 184-186; and General Comment No 23 , above n 2, para 9 .

${ }^{177}$ General Comment No 23, above n 2, para 6.1.
} 
requirement on a State is not to act to deny the right. ${ }^{178}$ For the reasons set out earlier about the right applying also to omissions, the requirement for a State to take active and protective steps where a minority language is vulnerable is consistent with the section 20 of the Bill of Rights Act.

Examples of the active role of the State can be reflected in the Māori Language Strategy developed by Te Puni Kōkiri ${ }^{179}$ and indirectly, as noted earlier, the Māori language planning resources developed by Māori Language Commission for use by the public and private sectors. ${ }^{180}$ Māori TV is also an example of proactive revitalisation of the Māori language and culture, although it is worth noting that this development draws much of its authority from the judicial decisions in the Mãori Council broadcasting cases.

\section{E Access to Redress}

Access to redress is not so much a guiding principle for action, but a "big stick" for promoting compliance with these principles. Where the State fails to fulfil its obligations, and its actions result in denial of the right, then the minority is entitled to redress. ${ }^{181}$ Claimants have access to the courts for redress where they consider their right to language has been breached under both the Treaty and the Bill of Rights Act. ${ }^{182}$ Further, claimants can lodge a communication with the UN Committee for breaches of the right to language after they have exhausted domestic judicial remedies. ${ }^{183}$ The Māori Council broadcasting cases illustrate that the role of the courts is that of a forum for redress where the State has failed to meet its obligations, although the court itself cannot prescribe the appropriate policy. ${ }^{184}$

\footnotetext{
${ }^{178}$ Mendelssohn, above n 44, paras 12-26.

179 See for example Te Puni Kōkiri Speakers of Mãori within the Mãori Population (Wellington, 2001); Te Puni Kōkiri Mãori Language in the Community (Wellington, 2004); and Te Puni Kōkiri

The Māori Language Strategy (Wellington, 2003).
${ }_{180}$ Māori Language Commission <www.tetaurawhiri.govt.nz/english/services_e/ intro_what.shtml> (last accessed 30 July 2006).

${ }^{181}$ New Zealand Mäori Council v Attorney-General, above n 55, 20 and 87 (HC) McGechan J.

182 See generally Guidelines on the New Zealand Bill of Rights Act 1990, above n 159, Part IV; and Rishworth, above n 61,811-838; and He Tirohanga o Kawa kit e Tiriti o Waitangi, above n 155, 100106.

${ }^{183}$ International Covenant on Civil and Political Rights, above n 21, Optional Protocol arts 2 and $5(2)(\mathrm{b})$.

${ }^{184}$ New Zealand Māori Council v Attorney-General, above n 107, 87 McGechan J. See also New Zealand Mãori Council v Attorney-General, above n 6, 588-589 (CA) Hardie Boys J.
} 
Neither the Treaty nor the Bill of Rights Act specify the types of remedies a court may award for an unjustified or unreasonable breach of the right to language. Remedies delivered under the Bill of Rights Act have generally focused the nature of the relief required to "cure" the breach, and been described as evolving and focusing on the individual circumstances of the case. Four main judicial considerations for determining relief have been summarised as: ${ }^{185}$

- the purpose and nature of the right infringed;

- the nature and seriousness of the beach;

- the consequences of the breach;

- what is necessary for the vindication of the right, rather than the punishment of the wrong-doer or compensation to the person affected.

The Butlers' Commentary notes that because breaches to section 20 can "manifest themselves in many ways and in a variety of settings" the remedies themselves are likely to be varied and go on to summarise the options of damages, judicial review, and declarations of inconsistency. ${ }^{186}$ In situations envisaged in this paper where a language is in need of revitalisation due to an "ongoing" breach, then the types of relief under both the Bill of Rights Act and the Treaty are likely to focus on securing a place for the language in government policies and administration such as eduction or broadcasting policies. Although the Māori Council was seeking injunctive relief to prevent the sale of broadcasting assets, the courts focused on shoring up Crown commitment to take policy action to address the vulnerable condition of the Māori language, and provide broadcasting opportunities. ${ }^{187}$ While it is plausible that a linguistic minority may seek monetary compensation where the State persists in breaching the right so as to fund their own policies - whether or not a court would grant such relief is unclear, and unlikely.

The UN Committee's findings are declaratory and do not propose the relief or redress. ${ }^{188}$ States are, however, required under article 2(3) of the ICCPR to ensure that there are effective remedies available for breaches of the right. Despite the lack

185 Guidelines on the New Zealand Bill of Rights Act 1990, above n 159, Part IV Remedies under the Bill of Rights Act.

${ }_{186}$ Butlers' Commentary, above n 80, paras 17.30-17.30.5

187 See for example New Zealand Māori Council v Attorney-General, above n 6, 588-589 (CA) Hardie-Boys J.

${ }^{188}$ Lovelace v Canada, above n 68, paras 17 and 19. 
of enforceability, New Zealand places great stock on being a good international citizen, ${ }^{189}$ and such a finding is likely to result in action so that New Zealand was in compliance with its international obligations under the ICCPR.

\section{CONCLUSION-RIGHT TO LANGUAGE IN NEW ZEALAND}

New Zealand has been progressively focusing its attention on what it means to be a New Zealander and how we want to be seen as a nation. ${ }^{190}$ Given language is one of the strongest markers of culture and identity, the right to language has contemporary significance for New Zealand.

\section{A Right to Language: Three Complementary Sources}

The right to language has three complementary sources in the New Zealand context: article 27 of the ICCPR, section 20 of the Bill of Rights Act, and article II of the Treaty (for the Māori and Moriori languages). All three formulations of the right to language place an obligation on the State to ensure members of linguistic minorities are able to use their own language in community with other members of their group and that the State's acts or omissions (or neglect) do not result in a denial of that right. The right to language is not absolute: it is subject to justified limitations (or in the case of the ICCPR if measures have a limited impact on the right are unlikely to result in an unjustified breach of the right to language). Limitations must have a significant and important objective and there needs to be a reasonable and proportionate connection between the limitation and that objective. Limitations must also be "prescribed by law", and there are no readily identifiable general limitations on the right to language in New Zealand law.

Where a minority language has become vulnerable due to past acts, omissions, or neglect then a State is required to take proactive steps to revitalise that language. The Māori Council broadcasting cases, general Bill of Rights jurisprudence, and the UN Committee's approach to the right to culture ${ }^{191}$ provide excellent authority for this finding. This is despite the somewhat narrow and disappointing Court of Appeal decision in Mendelssohn which decided that the right

\footnotetext{
189 See for example Ministry of Foreign Affairs and Trade Annual Report 2004/2005 (Wellington, 2005) 7 .

${ }^{190}$ See for example MCH Annual Report, above n 13,2. The Ministry of Culture and Heritage reports that our appetite for homegrown culture has never been stronger.

${ }^{191}$ General Comment No 23, above n 2, para 6.1.
} 
to culture affirmed in section 20 of the Bill of Rights Act does not impose positive duties on the State. Mendelssohn is, nevertheless, distinguishable on its facts as it involved a situation in which the plaintiff was seeking the State to intervene on his behalf with his religious commune: it did not involve a situation in which the State needs to take proactive steps to ensure its acts or omissions do not result in denial of the right nor is it a case where State action is required to revitalise a minority language or culture. The situations contemplated by this paper are situations where a State has positive duty to intervene.

The right to language has a relational aspect because an individual's ability to exercise the right is dependent on the language's well-being within the group. Therefore, where a minority language is in jeopardy the State's redress will need to target the language and linguistic minority as a whole. Economic constraints on a State are unlikely to be a successful reason for limiting State action to address a breach of the right to language, particularly, because redress can be achieved through progressive realisation: a programme for revitalising the minority language.

\section{B Observance of the Right to Language in New Zealand}

The Māori Council broadcasting cases found that te reo Māori was in a vulnerable condition and that State action was required. The steady progress made in developing a secure place for the Māori language is promising and reflects State observance of the right to language: it is important, however, to ward against complacency. Māori TV provides a good medium for conveying the language to a wider audience and capitalising on the work of Māori Language Commission. It is vital to continue to make the most of the gains in language acquisition and retention made over the last 20-30 years.

The Moriori language, in contrast, is in serious jeopardy and the State's failure to act is directly connected to the language's vulnerability. This neglect by the State is highly likely to result in findings of breach of the State's obligations under all three sources of the right to language. The Moriori language is in need of urgent attention: a language strategy (with an eye to the role of official recognition and television broadcasting as well as education) needs to be developed as a matter of priority.

Language acquisition through education is of primary importance for rescuing a vulnerable minority language. Official recognition (accompanied by a 
language commission style entity) and television broadcasting, however, provide solid opportunities to revitalise minority languages (whether indigenous or immigrant languages), and secure a meaningful place for them within the State and society. To succeed in revitalising a minority language and ensure State observance of the right to language, the Treaty principles offer sound guidance. These principles required the State be informed, act in partnership with the minority, take an active role, and ensure access to redress. These principles are complementary to the principles underpinning State action for observance of the right to language under the Bill of Rights Act and the ICCPR.

\section{Where to from here, New Zealand?}

Finally, the place of minority languages within our social, legal, and constitutional frameworks will require close consideration in New Zealand's reflection of its constitutional arrangements and direction as a nation. Walton makes the following observation about New Zealanders when advocating a written constitution for New Zealand: ${ }^{192}$

Michael King concluded in his Penguin History of New Zealand by saying that "most New Zealanders, whatever their cultural background, are good-hearted, practical, commonsensical and tolerant. Those qualities are part of the national character that has in the past saved this country from the worst excesses of chauvinism and racism seen in other parts of the world." The question, however, is how they will withstand the future.

Walton's warning is timely. Despite New Zealand's pragmatic attitude to problem solving, the position of ethnic and cultural minorities (both indigenous and immigrant) is one that will have to be addressed as part of New Zealand's development as a nation in the $21^{\text {st }}$ century. Ensuring minorities have their own voice and meaningful access to their language increases New Zealand's chances of promoting an inclusive, peaceful, and stable nation.

\footnotetext{
${ }^{192}$ Walton, above n $17,30-31$.
} 


\section{BIBLIOGRAPHY}

\section{A Primary Sources}

$1 \quad$ Legislation

Broadcasting Act 1989, ss 36 and 37, and Part 4A.

Human Rights Act 1993, s 21.

Māori Television Service (Te Aratuku Whakaata Irirangi Māori) Act 2003.

Māori Language Act 1987.

New Zealand Bill of Rights Act 1990, ss 3-6, 14, 19, 20, and 28.

New Zealand Sign Language Act 2006.

\section{$2 \quad$ International Instruments}

Charter of the United Nations (26 June 1945) UKTS 1946 No. 67.

Declaration on the Rights of Persons Belonging to National or Ethnic, Religious and Linguistic Minorities (18 December 1992) A/RES/47/135; reprinted in 32 ILM 911.

Draft United Nations Declaration on the Rights of Indigenous Peoples (UN SubCommission on Prevention of Discrimination and Protection of Minorities, 1994) E/CN.4/Sub.2/1994/56; reprinted in 34 ILM 541.

Indigenous and Tribal Peoples Convention 1989 No. 169 (27 June 1989) ST/HR/1/Rev.6(Vol.I/Part1); reprinted in 28 ILM 1382.

International Covenant on Civil and Political Rights (19 December 1966) 999 UNTS 171.

International Covenant on Economic, Social, and Cultural Rights (16 December 1966) 993 UNTS 3.

Vienna Convention on the Law of Treaties (22 May1969) 1155 UNTS 331.

3 Cases \& Views of the UN Human Rights Committee 
Ballentyne, Davidson \& McIntyre v Canada (5 May 1993) UN Human Rights Committee CCPR/C/47/D/385/1989.

Barzhig v France (6 May 1991) UN Human Rights Committee $\mathrm{CCPR} / \mathrm{C} / 41 / \mathrm{D} / 327 / 1988$.

Cadoret \& Le Bihan v France (11 April 1991) UN Human Rights Committee $\mathrm{CCPR} / \mathrm{C} / 41 / \mathrm{D} / 323 / 1988$.

Chief Bernard Ominyak and the Lubicon Lake Band v Canada (10 May 1990) UN Human Rights Committee CCPR/C/70/D/167/1984.

Diergaardt v Nambia (6 September 2000) UN Human Rights Committee CCPR/C/69/D/760/1997.

Fenwick v Trustees of Nga Kaihautu o Te Arawa Exeuctive Council (13 April 2006) HC ROT CIV-2004-463-847, Allan J.

Guesdon $v$ France (23 August 1990) UN Human Rights Committee CCPR/C/39/D/219/1986.

Keelan v Peach [2002] NZFLR 481 (HC).

Kitok v Sweden (10 August 1988) UN Human Rights Committee CCPR/C/33/D/197/1985.

Lansman $v$ Finland (26 October 1994) UN Human Rights Committee CCPR/C/52/D/511/1992.

Lawson v Housing New Zealand [1997] 2 NZLR 474 (CA).

Lovelace v Canada (30 July 1981) UN Human Rights Committee CCPR/C/13/D/24/1977.

Mahuika v New Zealand (15 November 2000) UN Human Rights Committee CCPR/C/70/D/547/1993.

Manukau v Attorney-General [2000] NZAR 621 (HC).

Mendelssohn v Attorney-General [1999] 2 NZLR 268 (CA).

Ministry of Transport v Noort (Police v Curran) [1992] 3 NZLR 260 (CA).

Moonen v Film and Literature Board of Review [1999] 2 NZLR 9 (CA).

Moonen v Film and Literature Board of Review [2002] 2 NZLR 754 (CA).

Ngati Apa ki te Waiponamu Trust v $R$ [2000] 2 NZLR 659 (CA).

New Zealand Māori Council v Attorney-General [1987] 1 NZLR 641 
New Zealand Mãori Council v Attorney-General (3 May 1991 \& 29 July 1991) HC WN CP 942-88, McGechan J.

New Zealand Māori Council v Attorney-General [1992] 2 NZLR 576 (CA).

New Zealand Mäori Council v Attorney-General [1994] 1 NZLR 513 (PC).

New Zealand Mäori Council v Attorney-General (29 March 1996) HC WN CP 40-96 McGechan J.

New Zealand Mäori Council v Attorney-General [1996] 3 NZLR 140 (CA).

Simpson v Attorney-General (Baigent's case) [1994] 3 NZLR 667 (CA).

Singh et al v Minister of Employment and Immigration [1985] 1 SCR 177.

Sunday Times v United Kingdom (1979) 2 EHRR 245.

Tainui Māori Trust Board v Attorney-General (1989) 2 NZLR 413.

4 Other

Cabinet Office Cabinet Manual 2001 (Wellington, 2001).

Cabinet Office Step by Step Guide: Cabinet and Cabinet Committee Processes 2001 (Wellington, 2001 as updated in September 2005).

Canadian Office of Commissioner of Official Languages <http://www.ocolclo.gc.ca/archives/ar_ra/2005_06/2005_06_e.pdf $>$ (last accessed 20 September 2006).

Constitutional Arrangements Committee "Inquiry to Review New Zealand's Existing Constitutional Arrangements" (2005) AJHR I.24A.

Department of Justice, A Bill of Rights for New Zealand: A White Paper (Government Printer, Wellington, 1985).

Māori Language Bill: (29 April 1986) 470 NZPD 1450-1468; (9 June 1987) 481 NZPD 9337-9343; (30 June 1987) 482 NZPD 10112-10115; (2 July1987) 482 NZPD 10207, (7 July 1987) 482 NZPD 10282-10283, (14 July 1987) 482 NZPD 10421 ; and (14 July 1987) 482 NZPD 10422-10423.

Māori Language Commission "Māori Language Planning - What is Language Planning?" <www.tetaurawhiri.govt.nz/english/services_e/intro_what.shtml> (last accessed 30 July 2006).

Mãori Television Service Annual Report 2004 (Auckland, 2004). 
Māori Television Service Annual Report 2005 (Auckland, 2005).

Māori Television Service Statement of Intent 2005/2006 (Auckland, 2005).

Māori Television Services Bill: (5 December 2001) 597 NZPD 13518-13534; (8 April 2003) 607 NZPD 4908-4924; (9 April 2003) 607 NZPD 4986 - 5030; (10 April 2003) 607 NZPD 5065-5082; (29 April 2003) 608 NZPD 5106-5113; (1 May 2003) 608 NZPD 5279-5291; and (6 May 2003) 608 NZPD 5350-5358.

Ministry of Culture and Heritage Annual Report 2005 (Ministry of Culture and Heritage, Wellington, 2005).

Ministry of Culture and Heritage Building a Stronger and Sustainable Public Broadcasting Environment for New Zealand - A Programme of Action $<$ www.mch.govt.nz/publications/public-broadcasting/public-bdcast.html> (last accessed 30 July 2006).

Ministry of Foreign Affairs and Trade Annual Report 2004/2005 (Ministry of Foreign Affairs and Trade, Wellington, 2005).

Ministry of Justice The Guidelines On The New Zealand Bill Of Rights Act 1990: A Guide To The Rights And Freedoms In The Bill Of Rights Act For The Public Sector (Wellington, 2004).

Ministry of Justice The Non-Discrimination Standards for Government and the Public Sector: Guidelines on how to apply the standards and who is covered (Wellington, 2002).

New Zealand Bill of Rights Bill: (10 October 1989) 502 NZPD 13047-13048, 13051-13053, and 13056-13057; (14 August 1990) 510 NZPD 3450; and (21 August 1990) 510 NZPD 3763-3765.

New Zealand Periodic Reports to United Nations Human Rights Committee, Third Periodic Reports of States parties due 1990: New Zealand 30 May 1994 CCPR/C/64/Add. 10.

New Zealand Periodic Reports to United Nations Human Rights Committee, Fourth Periodic Report of States parties due 1994: New Zealand, 7 March 2001, CCPR/C/NZL/2001/4.

New Zealand Sign Language Bill: (22 June) 618 NZPD 13774-13785.

Statistics Canada "Multicultural People" <http://142.206.72.67/02/02a /02a_007_e. htm\#t02> (last accessed 20 September 2006).

Statistics New Zealand 2001 Census of Population and Dwelling - Chatham Islands Community Profile <http://www2.stats.govt.nz/domino/external /web/CommProfiles.nsf/FindInfobyArea/597000-au> (last accessed 16 September 2006). 
Statistics New Zealand Census Snapshot: Cultural Diversity $<$ http://www.stats.govt.nz/products-and-services/Articles/census-snpsht-cultdiversity-Mar02.htm> (last accessed 23 September 2006).

Te Puni Kōkiri He Tirohanga o Kawa kit e Tiriti o Waitangi (Te Puni Kōkiri, Wellington, 2001).

Te Puni Kōkiri Speakers of Māori within the Māori Population (Wellington, 2001).

Te Puni Kōkiri Mãori Language in the Community (Wellington, 2004).

Te Puni Kōkiri The Mãori Language Strategy (Wellington, 2003).

United Nations Human Rights Committee "General Comment No.23" (8 April 1994) CCPR/C/21/REV.1/Add.5, para 9.

United Nations Human Rights Committee "Third Periodic Reports of States parties due 1990: New Zealand" (30 May 1994) CCPR/C/64/Add. 10.

United Nations Human Rights Committee "Fourth Periodic Report of States parties due 1994: New Zealand" (7 March 2001) CCPR/C/NZL/2001/4.

UN Sub-Commission on Prevention of Discrimination and Protection of Minorities "Siracusa Principles on the Limitation and Derogation of Provisions in the International Covenant on Civil and Political Rights" (1984) UN Doc E/CN.4/1984/4 Annex.

Waitangi Tribunal Rekohu: A Report on Moriori and Ngati Mutunga Claims in the Chatham Islands: Wai 64 (Wellington, Legislation Direct, 2001).

Waitangi Tribunal Te Reo Māori Claim: WAI 11 (Department of Justice, Wellington, 1986).

Welsh Language Board <www.bwrdd-yr-iaith.org.uk/cynnwys.php?pID $=104 \&$ langID $=2>$ (last accessed 8 August 2006).

\section{B Secondary Sources}

Addis, Adeno "Cultural Integrity and Political Unity: The Politics of Language in Multilingual States" (2001) 33 Ariz. St. L.J. 719.

Berlin, Isaiah Two Concepts of Liberty: An Inaugural Lecture delivered before the University of Oxford on 31 October 1958 (Clarendon Press, Oxford, 1959).

Blades, Alexander B "Article 27 of the International Covenant of Civil and Political Rights: A Case Study on Implementation on Civil and Human Rights in New Zealand" [1994] 1 CNLR 1. 
Butler, Andrew \& Petra Butler The New Zealand Bill of Rights Act: A Commentary (LexisNexis NZ Limited, Wellington, 2005).

de Cuellar, Javier Perez Our Creative Diversity. Report of the World Commission on Culture and Development (UNESCO, Paris, 1995).

Espiner, Colin "National's Reality" (24 July 2006) The Press Christchurch 9.

Fife, James "The Legal Framework for Indigenous Language Rights in the United States" (2005) 41 Willamentte L Rev 325.

Flavell, Te Ururoa MP "When an official language, isn't official" (23 June 2006) Press Release.

Harris, D J (ed) Cases and Materials on International Law (Sweet \& Maxwell, London, 1998) 484-519, 624-737, 806, and 813-817.

Hogg, Peter Constitutional Law of Canada (Looseleaf edition, vol 2, 1997).

Kāretu, T and J Waite "Te Reo Māori" in New Zealand Official Yearbook 1988-1989 (93 ed, Department of Statistics, Wellington, 1988) 217-227.

King, Michael Moriori: A People Rediscovered (Viking: Penguin Books (NZ) Ltd, Auckland, 1989).

King, Michael and Robin Morrison A Land Apart: The Chatham Islands of New Zealand (Random Century New Zealand Limited, Hong Kong, 1990).

McBride, Tim New Zealand Civil Rights Handbook: A guide to your civil rights under New Zealand Law (Legal Information Service Inc, Auckland, 2001).

Naffine, Ngaire "Assimilating Feminist Jurisprudence" (1993) 11 L in Context 7894.

New Zealand Government (48 ${ }^{\text {th }}$ Parliament) "Budget 2006 Theme 3 - National Identity" (18 May 2006) Press Release.

Piatt, Bill "Toward Domestic Recognition of a Human Right to Language" (1986) 23 Hous L Rev 885.

Rishworth, Paul (ed) The New Zealand Bill of Rights (Oxford University Press, 2002).

Thomas, Ben and David W Young "Tories go to cool school in battle of the brands" (28 July 2006) National Business Review Auckland13-01.

Thornberry, Patrick International Law and the Rights of Minorities (Clarendon Press, Oxford, 1991) ch14-28. 
Welch, Denis "Fatal Consequences" (27 May 2006) New Zealand Listener Auckland 21.

Tim Walton "Get it in writing" (5-11 August 2006) New Zealand Listener Auckland 26-32.

VIII SOME MĀORI \& MORIORI TERMS USED IN PAPER

\begin{tabular}{|c|c|}
\hline kura kaupapa Māori & A State school where teaching is in the Māori language. \\
\hline Māori & $\begin{array}{l}\text { Indigenous inhabitants of New Zealand } \\
\text { (See Part III A Māori Language) }\end{array}$ \\
\hline Moriori & $\begin{array}{l}\text { Indigenous inhabitants of Rekohu or Chatham Islands } \\
\text { (See Part III B Moriori Language) }\end{array}$ \\
\hline Pūkana & A children's educative television programme \\
\hline Rekohu & $\begin{array}{l}\text { Moriori name for the Chatham Islands } \\
\text { (See Part III B Moriori Language) }\end{array}$ \\
\hline tangata whenua & $\begin{array}{l}\text { The indigenous peoples of a country, often used to refer to } \\
\text { the Māori people. }\end{array}$ \\
\hline Taonga & $\begin{array}{l}\text { Is generally translated as "treasure" or "valued } \\
\text { possession". } \\
\text { (See Part II A } 3 \text { Protection of "native" languages) }\end{array}$ \\
\hline Te Karere & $\begin{array}{l}\text { A Māori news programme that screens on Television New } \\
\text { Zealand. }\end{array}$ \\
\hline Te Māngai Pāho & The Māori Broadcasting Funding Agency \\
\hline Te Puni Kokiri & $\begin{array}{l}\text { New Zealand Ministry of Maori Development } \\
\text { (See for example Part III A Māori Language) }\end{array}$ \\
\hline te reo Māori & The Māori language \\
\hline $\begin{array}{l}\text { Te Taura Whiri i te Reo } \\
\text { Māori }\end{array}$ & $\begin{array}{l}\text { Māori Language Commission } \\
\text { (See Part IV A Official Language) }\end{array}$ \\
\hline
\end{tabular}






$$
\begin{aligned}
& 25 / 2 \cdot 2012 \\
& 12 / 3-2012 \\
& 14 \text { MAR } 2012
\end{aligned}
$$

